NBER WORKING PAPER SERIES

\title{
ECONOMIC CONSEQUENCES OF HOUSING SPECULATION
}

\author{
Zhenyu Gao \\ Michael Sockin \\ Wei Xiong \\ Working Paper 26457 \\ http://www.nber.org/papers/w26457 \\ NATIONAL BUREAU OF ECONOMIC RESEARCH \\ 1050 Massachusetts Avenue \\ Cambridge, MA 02138 \\ November 2019
}

This paper supersedes an earlier draft circulated under the title "Housing Speculation and Supply Overhang." We are grateful to Gene Amromin, Barney Hartman-Glaser, Andrew Haughwout, Zhiguo He, Tim Landvoigt, Alvin Murphy, Charlie Nathanson, Monika Piazzesi, and seminar participants at the Federal Reserve Bank of New York, the University of Texas at Austin, the Wharton School, the American Economic Association Meetings, the American Finance Association Meetings, the CICF meetings, and the FRB Atlanta, GSU Real Estate Finance, and Texas Finance Festival Conference for helpful comments and discussion. The views expressed herein are those of the authors and do not necessarily reflect the views of the National Bureau of Economic Research.

NBER working papers are circulated for discussion and comment purposes. They have not been peer-reviewed or been subject to the review by the NBER Board of Directors that accompanies official NBER publications.

(C) 2019 by Zhenyu Gao, Michael Sockin, and Wei Xiong. All rights reserved. Short sections of text, not to exceed two paragraphs, may be quoted without explicit permission provided that full credit, including $\left({ }^{\circ}\right.$ notice, is given to the source. 
Economic Consequences of Housing Speculation

Zhenyu Gao, Michael Sockin, and Wei Xiong

NBER Working Paper No. 26457

November 2019

JEL No. E3,R31

\section{ABSTRACT}

By exploiting variation in state capital gains taxation as an instrument, we analyze the economic consequences of housing speculation during the U.S. housing boom in the 2000s. We find that housing speculation, anchored, in part, on extrapolation of past housing price changes, led not only to greater price appreciation, economic expansions, and housing construction during the boom in 2004-2006, but also to more severe economic downturns during the subsequent bust in 2007-2009. Our analysis supports supply overhang and local household demand as two key channels for transmitting these adverse effects.

Zhenyu Gao

Chinese University of Hong Kong Hong Kong gaozhenyu@baf.cuhk.edu.hk

Michael Sockin

Department of Finance

UT Austin McCombs School of Business Austin, TX 78712

michael.sockin@mccombs.utexas.edu
Wei Xiong

Princeton University

Department of Economics

Bendheim Center for Finance

Princeton, NJ 08450

and NBER

wxiong@princeton.edu 
Economists have long been concerned with the economic consequences of speculation and asset bubbles. A growing strand of the literature, including Shiller (2009), Haughwout et al. (2011), Barlevy and Fisher (2011), Mayer (2011), Case, Shiller, and Thompson (2012, 2015), Bayer et al. (2015), Chinco and Mayer (2016), Albanesi, De Giorgi, and Nosal (2017), DeFusco, Nathanson, and Zwick (2017), Nathanson and Zwick (2017), and Soo (2018) has highlighted the importance of housing speculation in driving the recent housing cycle. ${ }^{1}$ Housing speculation became a national phenomenon in the low interest rate environment of the mid-2000s, with purchases of non-owneroccupied homes (second and investment homes) contributing up to $30 \%$ of all home purchases during the boom in cities such as Las Vegas. Housing speculation also represented a source of housing demand largely orthogonal to the credit expansion to subprime households that occurred during the housing boom, which is widely regarded, for instance by Mian and Sufi (2009), Keys et al. (2009), and Justiano et al. (2017), as a key driver of the boom. Interestingly, areas in which speculation became more prevalent during the boom period experienced local economic expansions, while subprime credit expansion occurred more in areas that experienced local economic contractions. In addition, while supply inelasticity and non-recourse mortgage laws have a positive and statistically significant correlation with the fraction of subprime mortgages in a zip code, they have an opposite, smaller, and less significant correlation with housing speculation. ${ }^{2}$ As such, speculation represents an important complementary channel in explaining the crosssectional variation in the housing and economic cycles across the U.S. during the 2000s.

An intuitive hypothesis posits that speculation in the housing market can have important economic consequences. Housing speculation, anchoring on extrapolative expectations of past housing price growth, can amplify local economic conditions by contributing a non-fundamental source of demand to housing markets. When these speculators purchase more non-owner-occupied homes in an area during a housing boom, their speculation can magnify the boom and contribute not only to a greater price drop, but also to a more severe economic contraction, during the subsequent housing bust. Despite its intuitive appeal, this hypothesis remains elusive to test because of the well-appreciated endogeneity issue with identification, i.e., housing speculation

\footnotetext{
${ }^{1}$ Glaeser (2013) provides an eloquent analysis of nine episodes of real estate speculation in American history and highlights housing speculation as one of several recurring themes in these episodes.

2 This opposite and less significant correlation suggests that studies that instrument the housing price boom with supply elasticity or variation in non-recourse mortgage laws are capturing the impact of subprime rather than speculation.
} 
may reflect local housing demand or other unobservable economic conditions, rather than be a cause of housing and economic cycles.

In this paper, we undertake this challenge to study how housing speculation contributed to higher housing prices and local economic expansions during the boom period of 2004-2006, and adversely affected economic activity during the bust period of 2007-2009. We measure housing speculation during the boom by the fraction of non-owner-occupied home purchases in a zip code, which conveniently measures the intensity of housing speculation relative to primary home demand. For identification, we construct a novel instrument for housing speculation that takes advantage of the variation across U.S. states in their taxation of capital gains. While homeowners can exclude capital gains from the sale of their primary residence from their income taxes, this exclusion does not cover capital gains from selling non-owner-occupied homes. As U.S. states have significant variation in how they tax capital gains, housing speculation is more intensive in states with either no or low capital gains taxes. We therefore construct our instrument as the marginal tax rate for the median income household in each state.

By instrumenting non-owner-occupied home purchases with the capital gains tax variable, we find that zip codes with a greater share of non-owner-occupied home purchases during the boom had not only more pronounced housing cycles during the boom and bust, but also experienced greater swings in employment, payroll, per capital income, and the number of business establishments. The economic magnitude of these effects is substantial: an increase of 9.9\% (one standard deviation across zip codes) in the share of non-owner-occupied home purchases in 2004-2006 led to a housing price increase of 26.5\% during the boom, and a drop of $37.4 \%$ during the bust. Similarly, this increase led to an increase of $13.7 \%$ in real payroll, $8.4 \%$ in employment, $12.9 \%$ in per capita income, and $6.8 \%$ in the number of establishments from 20042006. During 2007-2009, in contrast, it contributed to declines of $15.4 \%$ in real payroll, $14.6 \%$ in employment, $7.8 \%$ in income per capita, and $8.7 \%$ in the number of establishments. These results on the impact of housing speculation are robust to excluding the so-called "sand states" of Arizona, California, Florida, and Nevada that saw particularly phenomenal housing cycles. Furthermore, our analysis shows that, among states with lower capital gains taxes, the share of non-owneroccupied home purchases responds more strongly to past housing price increases, even after 
controlling for past changes in local housing fundamentals. This finding supports extrapolative expectations as a key driver of housing speculation.

We also examine two transmission mechanisms to understand how housing speculation during the boom propagated to the real economy during the bust. The first is the supply overhang channel, explored, for instance, in Rognlie, Shleifer, and Simsek (2015). By again using the instrumental variable approach, we find that areas with more intensive housing speculation during the boom also had a greater increase in housing construction in the same period, which, in turn, contributed to the subsequent contraction of the construction sector during the bust. An increase of one standard deviation in instrumented housing speculation in 2004-2006 led to an increase of $4.2 \%$ in building permits in 2004-2006, relative to the number of housing units in 2000, and decreases of $33.8 \%$ in construction-sector employment and $12.4 \%$ in non-construction sector employment in 2007-2009. These findings confirm the importance of the supply overhang channel.

To further explain the substantial downturn experienced by non-construction sectors, we also examine a second transmission channel, local household demand, as suggested by Mian, Rao, and Sufi (2013) and Mian and Sufi (2014), by analyzing the impact of housing speculation on nontradable sectors - and the retail and restaurant sectors more narrowly — which primarily rely on local consumption demand. We find significant real effects through this channel. An increase of one standard deviation in instrumented housing speculation in 2004-2006 led to a decrease of $15.1 \%$ in non-tradable sectors' employment in 2007-2009, and a decline of $15.6 \%$ in the retail and restaurant sectors, specifically. ${ }^{3}$ In contrast, housing speculation had a more modest effect on employment in tradable sectors and in industries other than retail and the restaurant business.

While our tax instrument allows us to establish and quantify the causal link between housing speculation, housing prices, and real activity, an important limitation is that it relies on state-level variation. As such, we do not have a source of within-state exogenous variation in the fraction of non-owner-occupied home purchases for the first stage of the IV test. While this lack of granularity is not ideal for our analysis of housing speculation at the zip-code level, this limitation biases our results against finding supportive evidence for the housing speculation hypothesis. Nevertheless,

\footnotetext{
${ }^{3}$ Kaplan, Mitman, and Violante (2017), through the lens of a quantitative framework, also find that a shift in household expectations of future capital gains on housing investments deepened the Great Recession through the household balance sheet channel.
} 
this instrument provides sufficient cross-sectional variation to identify the economic consequences of housing speculation.

Our study contributes to the rapidly growing literature on housing speculation. Using creditreport data, Haughwout et al. (2011) document a large increase in the share of housing purchased by real estate investors during the recent U.S. housing boom, who took on more leverage and had higher default rates during the bust. Using micro-level data, Chinco and Mayer (2016) show that speculation by investment-home buyers played an important role in the dramatic house price boom and bust cycles in 21 cities, including Las Vegas, Miami, and Phoenix. Nathanson and Zwick (2017) turn to speculation in the land market and investigate how land investment by homebuilders shapes the house price boom in areas with elastic housing supply. DeFusco, Nathanson, and Zwick (2017) investigate the importance of short-term real estate investors in explaining housing price and volume dynamics in the recent housing cycle. While most of these studies have explored the relation between speculation and housing market outcomes, such as house prices and default, we provide causal evidence that speculation exacerbated the recent U.S. housing cycle. In addition, we investigate its causal impact on local economic activity, including establishments, payroll, employment, and per capita income growth, during both the housing boom and bust. We also highlight the interaction between state capital gains, speculation, and extrapolation of past housing price appreciation as a potential explanation for the cross-sectional variation in housing speculation. Last, we investigate potential transmission mechanisms through which housing speculation during the boom propagated to the real economy during the bust.

Our work is also related to the literature on the economic distortions of housing booms. Chen et al. (2016) show that firms responded to rising real estate prices in China by diverting resources from their core businesses to real estate investment. Charles, Hurst, and Notowidigdo (2016a, 2016b) explore how the housing boom led to distortions in the employment and educational attainment decisions predominantly among low-skilled, prime-aged laborers by temporarily expanding the construction and services sectors. Consistent with their results, we find that construction and local retail and service sectors contracted during the housing bust.

While our study focuses on the role of housing speculation in explaining the recent U.S. housing cycle, the housing literature has explored several other mechanisms. Himmelberg, Mayer, 
and Sinai (2005) and Mayer and Sinai (2009), for instance, focus on the role of interest rates, while Favilukis, Ludvigson, and Van Nieuwerburgh (2015) emphasize the relaxation of borrowing constraints. Mian and Sufi (2009, 2011) and Favara and Imbs (2015) link the surge in household debt and house prices during the recent housing cycle to an expansion in the supply of credit that resulted from securitization and subprime lending, Landvoigt, Piazzesi, and Schneider (2015) also emphasize the role of cheap credit for poor households in driving house price dynamics, and Mian and Sufi (2010) examine the relation between this buildup and the cross-section of house price booms and busts in the recent cycle. Furthermore, Keys et al. (2009, 2010), Purnanandam (2011), and Griffin and Maturana (2015, 2016), among others, highlight that agency issues associated with securitization may have helped fuel this credit expansion. Along this dimension, Griffin and Maturana (2015) document the importance of mortgage origination misreporting by the worst originators in explaining housing price booms and busts. Similarly, Mian and Sufi (2015) show mortgage fraud to be associated with low income zip codes that exhibited the strongest mortgage credit growth in 2002 to 2005 . The speculation channel that we analyze is distinct from that of fraud and misreporting, as our results remain robust when we control for the misreporting measure of Piskorski, Seru, and Witkin (2015). To the extent that the credit expansion and agency issues in mortgage origination facilitated participation by optimistic speculators in housing markets during the boom, we view these channels as being complementary.

\section{Empirical Methodology}

We aim to examine the economic impact of housing speculation during the boom and bust cycle of the U.S. housing markets in the 2000s. The literature has established that this housing cycle was, in part, driven by a credit expansion to households across the country, which was precipitated by the rapid growth of securitization and shadow banking in the early 2000s, e.g., Mian and Sufi (2009) and Keys et al. (2010). While this was a national housing cycle, there was substantial variation across regions. We are interested in testing whether housing speculation contributed to this cross-region variation and, specifically, whether housing speculation during the boom affected the housing cycles and economic performance during the subsequent downturn. ${ }^{4}$

\footnotetext{
${ }^{4} \mathrm{We}$ focus on the recent U.S. housing cycle of the 2000s because the data are more complete for this period than for earlier years, and because the national housing cycle allows us to directly compare the cross-sectional variation in
} 
To facilitate our cross-region analysis during this national cycle, we divide the housing cycle into three phases: 2001-2003 as the pre-boom period, 2004-2006 as the boom period, and 20072009 as the bust period. ${ }^{5}$ We define 2004-2006 as the boom period because housing speculation, as we will show, was most intensive during this period. Anchoring on this three-year boom period, we analyze how housing price growth in the previous three years (the pre-boom period) stimulated housing speculation during the boom through home buyers' extrapolative expectations, and how housing speculation during the boom affected local economic performance both during the boom period and the subsequent three years (the bust period).

We measure housing speculation in an area in a given year by the fraction of non-owneroccupied homes in all home purchases financed by mortgages. Since non-owner-occupied homes provide less housing service to their owners than primary homes, the decision to purchase a nonowner-occupied home is driven to a greater extent by buyers' speculative motives than their decision to purchase a primary home. ${ }^{6}$ As such, the fraction of non-owner-occupied home purchases provides a convenient and intuitive measure of the intensity of housing speculation relative to primary housing demand.

We face the typical issue of endogeneity in testing the impact of housing speculation. A large fraction of non-owner-occupied home purchases in an area might reflect local economic conditions rather than be a cause of housing and economic cycles. To address this challenging identification issue, we need an instrumental variable that exogenously affects housing speculation in an area.

To construct such an instrument, we take advantage of the heterogeneity in capital gains taxes imposed across different states. The primary residence exclusion allows homeowners to exclude

\footnotetext{
housing markets and local economic conditions. Such a cross-sectional analysis is not feasible for the earlier housing cycles of the 1980s and 1990s, as they were asynchronous and experienced by only a few cities.

${ }^{5}$ This definition is largely consistent with the timing convention in the literature. In particular, 2006 is widely recognized as the turning point of the cycle, as noted by Glaeser (2013). Haughwout et al. (2013) define the boom period as 2000-2006, and the bust period as 2007-2010. Ferreira and Gyourko (2018) find that the start of the house price boom was not synchronized across the U.S. and house prices for each zip code also peaked in different months. Since our speculation measure and several economic outcome variables are at the annual frequency, we use 2006 as the turning point of housing cycles across regions.

${ }^{6}$ This measure does, however, have its limitations. For instance, investors may purchase their houses for vacation purposes. Non-owner-occupied house purchases could also be affected by demand from renters and new migrants. To address this issue, we include various local characteristics, such as the fraction of employment in the sectors of art, entertainment, and recreation, the ratio of renters, as well as the fraction of migrants, as controls in our analysis.
} 
up to $\$ 250,000$ ( $\$ 500,000$ per couple) of capital gains from the sale of their primary residence, at both the federal and state levels, defined as a home that they have owned and lived in for at least two of the five years prior to the sale. As there is no capital gains exclusion for sales of non-owneroccupied homes during the recent housing boom, buyers of non-owner-occupied homes are subject to capital gains taxation.

Taxation of capital gains at the state level is similar to that at the federal level, but different states impose different capital gains tax rates, and nine states (i.e., Alaska, Florida, Nevada, New Hampshire, South Dakota, Tennessee, Texas, Washington, and Wyoming) impose no capital gains taxes at all. The choice of capital gains tax rates are not driven by shocks to housing markets. In fact, during the boom period of 2004-2006, all of these nine states remained without capital gains taxes, and only the District of Columbia and Ohio slightly changed their capital gains tax rates. ${ }^{7}$

There is ample evidence showing that economic agents across the U.S. were overly optimistic about the housing market. ${ }^{8}$ As optimistic households might choose to buy investment homes, state capital gains taxes provide a source of exogenous variation in the fraction of non-owner-occupied home purchases across areas. In particular, optimistic buyers expect to realize a capital gain rather than a loss on the sale of an investment home. As such, capital gains taxes would have a negative impact on investment home purchases. The magnitude of this impact could be substantial: as reported by the Bureau of Census, the average sales price for houses sold in 2003 is $\$ 244,550$ dollars. For a back-of-the-envelope calculation, using the summary statistics in our sample in Panel A of Table 1, the capital gains would be, on average, $\$ 68,000$ dollars if one purchased a house in 2003 and sold it in 2006. This sale would incur a tax of $\$ 3,400$ dollars for a $5 \%$ average state capital gains tax.

That capital gains taxation represents an important margin for home buyers and sellers can be seen by revealed preference from the passage of the Taxpayer Relief Act of 1997. This act introduced the exclusion of capital gains from the sale of primary residences at the federal level.

\footnotetext{
${ }^{7}$ For a median income household, the marginal capital gains tax rate changed from $9 \%$ to $8.7 \%$ in the District of Columbia and from $4.983 \%$ to $4.764 \%$ in Ohio from 2005 to 2006.

${ }^{8}$ Even credit rating agencies, such as Moody's, calculated the credit risk of mortgage-backed securities during the boom period under the assumption that housing prices would not decline in the near future. In addition, Cheng, Raina, and Xiong (2014) find that a sample of securitization agents also increased their own exposures to housing in 20042006.
} 
States followed suit in honoring this exclusion, providing an additional windfall to their residents. Shan (2011) studies housing market behavior after the passage of the act and finds that the semiannual housing sales rate increased by 17 to $24 \%$ from baseline levels for homeowners with capital gains between $\$ 0$ and $\$ 500,000$, with an elasticity of -0.1 to $-0.2 \%$ in home sales for a $\$ 10,000$ increase in capital gains taxes. That some states have extended the capital gains exclusion to secondary homes since the financial crisis suggests that taxes on capital gains are a relevant margin in home buyer decisions.

Motivated by this observation, we instrument the fraction of non-owner-occupied home purchases during the boom period of 2004-2006 with a tax variable that incorporates the marginal capital gains tax rate across states. This variable is equal to zero in states with no capital gains taxes and the marginal tax rate for a median income household in states with capital gains taxes. ${ }^{9}$ In using this instrument, we implicitly assume that the marginal buyer of non-owner-occupied homes is an in-state resident. According to a survey by the National Association of Realtors (2015), the typical investment property is 24 miles from the buyer's primary residence. This finding suggests that the typical investment home buyer is likely to be in-state, supporting the relevance requirement of our instrument. ${ }^{10}$ In Section II, we also conduct a border analysis for states without capital gains taxes to provide evidence of the relevance of state capital gains taxes as an instrument for housing speculation.

For our instrument to be valid, it also needs to satisfy the exclusion restriction for causality with respect to the housing boom and the subsequent housing bust and economic contraction. ${ }^{11}$

\footnotetext{
${ }^{9}$ Albanesi, DeGiorgi, and Nosal (2017) provides evidence that real estate investors during the housing boom were concentrated in the middle and upper echelons of the income distribution. We have also verified that our results are robust to using instead the top marginal capital gains tax rate or a dummy indicator variable of whether a state has a capital gains tax.

${ }^{10}$ Investment home buyers from out of state introduce a nuanced issue. A buyer expects to pay taxes on future capital gains in both states - the state of residence and the state where the home resides - but may receive tax credits from the state of residence to offset the double tax incidence. The buyer thus pays the higher tax rate between the two states. We expect this issue to mostly affect zip codes close to the state border. In Section B of the Internet Appendix, we repeat our empirical tests after splitting zip codes into two subsamples: 1) zip codes within 50 miles of state borders, and 2) zip codes further than 50 miles from state borders. Consistent with our relevance assumption, the impact of housing speculation on housing prices and real outcomes is quantitatively more pronounced in the second subsample, where there is likely less noise from incorrect assignment of the tax treatment to non-owner-occupied home purchases. Our results are still quantitatively and statistically significant for the first subsample, despite this classification issue.

${ }^{11}$ One concern is that although homeowners can exclude up to $\$ 250,000$ ( $\$ 500,000$ per couple) of capital gains from the sale of their primary residence, the capital gains taxes could still affect households' primary home demand. As
} 
While economic activity in a state might be related to its treatment of state-level personal taxation, our analysis requires only that, in absence of omitted variables correlated with both taxes and changes in housing prices, the relative magnitudes of the housing boom and bust and real outcomes during the Great Recession were not directly driven by variation in state-level capital gains taxation during the boom period. ${ }^{12}$ We believe that this is the case for several reasons.

First, capital gains taxation is only a part of state taxes. As summarized by Fajgelbaum et al. (2018), there are several sources of state tax revenue, such as personal income taxes, corporate income taxes, general sales taxes, selective sales taxes (e.g., alcohol sales taxes), and license taxes, which accounted, respectively, for $35 \%, 7 \%, 32 \%, 15 \%$, and $6.2 \%$ of total state tax revenue in 2017. Capital gains taxes are part of personal income taxes, and there is substantial variation across states in the total state tax revenue, as well as in the rate for each of these tax components. There is little evidence suggesting that state fiscal policies and capital gains taxation impact local economic activity. Da et al. (2016) documents that state fiscal policies have a negligible effect on firm cash flows, and only impact discount rates if a firm has a concentrated investor base. Several studies, including Walden (2014) and Gale, Krupkin, and Reuben (2015), also find little relation between the relative size of the public sector (state and local taxes as a percentage of personal income) and state differences in economic growth during the recent recovery. In addition, as a small portion of state tax revenue, capital gains taxes are even unlikely to affect economic performance directly.

Second, to directly test for a potential relation of state capital gains taxation with housing prices and local economic activity, we conduct several placebo tests, available in Section A of the Internet Appendix, for the pre-sample period of 1999 to $2001 .{ }^{13} \mathrm{We}$ find an economically and statistically insignificant link between state capital gains taxation and housing market and economic outcomes during this period.

\footnotetext{
we construct our speculation measure as the fraction of non-owner-occupied homes in all home purchases, we filter out the potential effect of the primary home demand to mitigate this concern.

${ }^{12}$ We use the level of, rather the change in, state capital gains taxes as our instrument. The level was stable during the period of 2004-2006. While change in taxation might shock housing markets and local economies directly, the level of state capital gains taxation likely affected only housing speculators' decisions when widespread optimism arose during the boom period.

${ }^{13}$ We report the results for this pre-sample period because the data from the IRS start from 1998. The results are also insignificant for the variables available in the Zip Code Business Patterns database since 1994.
} 
Third, we perform several Granger causality tests, available in Section E of the Internet Appendix, and find that neither contemporaneous, lagged, nor leading changes in housing prices or economic performance can predict state capital gains taxation from 1978 to $2010 .{ }^{14}$ The lack of any evidence directly linking state capital gains taxation to housing market and economic outcomes ensures the validity of our instrument.

\section{Data Description}

Panel A of Table 1 provides summary statistics for a set of variables used in our analysis.

Housing speculation: The Home Mortgage Disclosure Act (HMDA) data set includes comprehensive individual mortgage application and origination data for the U.S. It discloses owner occupancy for each individual mortgage and indicates whether the mortgage is for a primary residence or a non-owner-occupied home. We aggregate the HMDA data to the zip code level and calculate the fraction of mortgage originations for non-owner-occupied homes in the total mortgage origination as our measure of the share of non-owner-occupied home purchases. ${ }^{15}$ The fraction of non-owner-occupied home purchases in 2004-2006 has a mean of 13.6\% and a standard deviation of $9.9 \%$ across zip codes.

Figure 1 depicts the fraction of non-owner-occupied home purchases for the U.S. and three cities, New York, Las Vegas, and Charlotte, from 2000 to 2010. Non-owner-occupied home purchases represent a sizable fraction of mortgage originations, comprising $15.31 \%$ of all new originations in the U.S. at its peak in 2005. While this measure of non-owner-occupied home purchases contains both second home and investment home purchases, both types of home

\footnotetext{
${ }^{14}$ Specifically, we run the state-level panel regressions of marginal state capital gains tax rate for $\$ 50,000$ in income (in 2005 USD) on contemporaneous, lagged (one or five years), or leading (one or five years) changes in housing prices, and economic performance including wages and salaries, number of establishments, employment, per capita income, and unemployment rate. We also control for the corporate tax rate, sales tax rate, and year fixed effects. We find similar results for the $\$ 10,000, \$ 25,000, \$ 75,000$, and $\$ 100,000$ income brackets. We also find similar results if, instead of one and five year leads and lags, we use two, three, or four years. These state-level variables are from Serrato and Zidar (2018) and NBER TAXISM.

${ }^{15}$ Haughwout et al. (2011) use the FRBNY Consumer Credit Panel to determine housing investors based on the number of first-lien mortgage accounts that appear on their credit reports. Their proprietary data are more reliable than the HMDA data. Chinco and Mayer (2016) identify out-of-town second home buyers by distinguishing between the property and tax bill mailing addresses in transaction deeds. These data, however, are not as comprehensive as the HMDA data with which we are able to conduct a nationwide analysis of housing markets.
} 
purchases are at least partially influenced by the motive to speculate on housing price appreciation, which became a national phenomenon in the low interest rate environment of the mid-2000s. Among the three cities, Las Vegas had the highest fraction of non-owner-occupied home purchases, which rose from a level $17.77 \%$ in 2000 to $29.41 \%$ in 2005 , and then dropped back down to $17.77 \%$ in 2008. New York had the lowest fraction, which, while having a synchronous rise and fall with the other two cities, remained below $7 \%$ during this period.

One may be concerned that our measure of speculation has substantial measurement error because it does not include investment home purchases made in cash, and there is evidence of systematic misreporting of owner occupancy by banks to MBS investors, for instance in Piskorski, Seru, and Witkin (2015). Consistent with the intuition that our measure of speculation underestimates the true level of speculation in a zip code, Table C2 in Section C of the Internet Appendix confirms that the OLS estimates of all our coefficients of interest are biased downward compared to their IV counterparts. To address the potential issue that our results may be driven by fraud from misreporting, rather than speculation itself, we add the misreporting measure from Piskorski, Seru, and Witkin (2015), which measures the mean fraction of loans in a zip code with undeclared second-liens or non-owner occupancy status, as a control in all our main regressions in Section D of the Internet Appendix. ${ }^{16}$

Capital gains instrument: We use the historical state capital gains tax rate as a key instrument for our analysis of housing speculation. Specifically, we collect state capital gains tax data from the Tax Foundation and state median income data from the American Community Survey conducted by the Census Bureau. We construct the measure of the capital gains tax burden on housing speculation at the state level based on the historical tax schedule in these states. We exploit variation in the state capital gains taxation by measuring the marginal capital gains tax burden for the median-income residents within a state in 2005. Figure 2 displays a map of the distribution of capital gains taxes at the state level. As shown in this figure, there are nine states without capital gains tax: Alaska, Florida, Nevada, New Hampshire, South Dakota, Tennessee, Texas, Washington, and Wyoming. For states with capital gains taxes, the marginal capital gains

\footnotetext{
${ }^{16} \mathrm{We}$ do not control for it in our main tables because of the loss of zip code observations in matching the data.
} 
tax rates range from $2.1 \%$ in states such as North Dakota to $9 \%$ in states such as Oregon. The mean of the tax burden on the intensive margin is $4.77 \%$ and the standard deviation is $1.27 \% .^{17}$

To demonstrate that state capital gains taxes influenced speculation during the boom period, we perform a border analysis by examining zip codes within 50 miles of the border of states with zero capital gains taxes, excluding Alaska. ${ }^{18}$ Panel A of Table 2 tests for a jump across borders in the fraction of non-owner occupied home purchases from 2004 to 2006 and in the fraction of subprime mortgages in 2005, and reveals that the dummy for whether the state has capital gains taxes significantly negatively predicts our measure of speculation, but has no impact on subprime credit expansion. The fraction of non-owner-occupied home purchases jumps by $4.9 \%$, and this economic magnitude is substantial relative to its mean of $13.6 \%$ and standard deviation of $9.9 \%$. Panel A of Figure 3 confirms graphically that there is a discontinuous jump in the fraction of nonowner-occupied home purchases at the state borders when plotting the coefficients from the distance regression, while Panel B demonstrates that there is no discernable analogous jump in the fraction of subprime mortgages. To further confirm that our instrument captures only variation in housing speculation, Panel B of Table 2 reports results from border regressions of the tax dummy on all our control variables and reveals that all coefficients are statistically insignificant. Our border analysis consequently provides evidence that our instrument satisfies the relevance condition, and that it instruments for housing speculation and not for subprime credit expansion.

House prices: We use zip code level house price data from the Case-Shiller Home Price indices, which are constructed from repeated home sales. ${ }^{19}$ We further deflate the Case-Shiller Home Price Indices with the Consumer Price Index (CPI) from the Bureau of Labor Statistics. The real house price change has a mean of $27.8 \%$ in 2004-2006 across the zip codes in our sample, and a mean of $-41.3 \%$ in $2007-2009$.

\footnotetext{
${ }^{17}$ Table $\mathrm{C} 1$ in Section $\mathrm{C}$ of the Internet Appendix reports reduced-form regressions of house price changes and all our economic outcomes during the cycle on the tax instrument. While the coefficients are not economically interpretable in the context of housing speculation, their statistical significance provides evidence of an economic link between our tax instrument and economic outcomes, which is central for our IV regressions.

${ }^{18}$ Mian, Sufi, and Trebbi (2015) used a similar zip code-level analysis around state borders with different foreclosure laws to justify state judicial requirements as an instrument for foreclosures. They find a jump in the foreclosure rate at the border between a judicial and a non-judicial state.

${ }^{19}$ All our results are quantitatively similar, and remain significant, if we instead use Zillow housing price indices as our measure of local housing prices. These results are reported in Section F of the Internet Appendix.
} 
Figure 4 displays the Case-Shiller real house price indices for the U.S. and three cities, New York, Las Vegas, and Charlotte, from 2000-2010. The national housing market experienced a significant boom and bust cycle in the 2000s with the national home price index increasing over $60 \%$ from 2000-2006, and then falling back to its 2000 level in 2007-2009. New York had a real housing price appreciation of more than $80 \%$ during the boom and then declined by over $25 \%$ during the bust. Charlotte had an almost flat real housing price level throughout this decade. Interestingly, Las Vegas, which had the most dramatic rise and fall in non-owner-occupied home purchases, also experienced the most pronounced housing price expansion-over 120\%—during the boom, and the most dramatic housing price drop-over 50\%_during the bust.

Local economic performance: We collect data on economic performance at the zip code level from various sources. Annual population and annual per capita income at the zip code level are available from the Internal Revenue Service (IRS). The IRS does not, however, provide data for 2000 and 2003. We therefore use the data for 2002 and 2006 to calculate the changes during the boom period and the changes from 2001 to 2002 for the pre-boom period. Annual total employment, annual payroll, and the number of establishments at the zip code level are available from the Zip Code Business Patterns database. We include both resident income and annual payroll from employers because, as argued by Mian and Sufi (2009), residents in a certain area do not necessarily work in the same place that they live. The change in per capita income has a mean of $5.2 \%$ in $2003-2006$ and a mean of $-11.3 \%$ in $2007-2009$, which is consistent with the dramatic economic expansion and recession during the boom and bust period. Similarly, the employment change has a mean of $7.1 \%(-8.3 \%)$, the change in the number of establishments has a mean of $6.4 \%(-3.8 \%)$, and the real payroll change has a mean of 8.7\% (-10.0\%) in 2004-2006 (2007-2009).

Zip Code Business Patterns database also provides employment data by establishment size and by industry. For our analysis, we are interested in the construction industry as it is directly related to the supply side of housing markets. We also follow Mian and Sufi (2014) to identify non-tradable industries because they produce non-tradable goods and services, which reflect the strength of local demand. Alternatively, we examine the retail and restaurant industries, which rely on local consumption.

New housing supply: To measure supply-side activities in local housing markets, we use building permits from the U.S. Census Bureau, which conducts a survey of permit issuing all over 
the U.S. Compared with other construction-related measures, such as housing starts and housing completions, building permits are more detailed and available at the county level. In addition, building permits are issued before housing starts and can therefore predict price trends in a timely manner. ${ }^{20}$ A potential weakness of this measure, however, is that the Census Bureau does not provide building permit data at the zip code level. Specifically, using 2000 U.S. census data, we measure new housing supply at the county level during the boom period by the building permits issued from 2004 to 2006 relative to the existing housing units in $2000 .{ }^{21}$ This measure has a mean of $5.6 \%$ across counties in our sample and a substantial standard deviation of $5.6 \%$.

Figure 5 depicts the annual building permits granted in 2000-2010 relative to the number of housing units in 2000 for the U.S. and for three cities, New York, Las Vegas, and Charlotte. At the national level, annual building permits had a modest increase from $1.05 \%$ in 2000 to $1.45 \%$ in 2005 and then a substantial drop to $0.38 \%$ in 2009. New York saw very little increase in its housing supply, with annual building permits staying at a flat level of less than $0.4 \%$ throughout this decade. Charlotte had a larger increase in supply than New York in the 2000s. Interestingly, Las Vegas had the most dramatic rise and fall in annual building permits, rising from $2.03 \%$ in 2000 to a level above $5 \%$ in 2005 and 2006, and then dropping to $0.50 \%$ in 2009, roughly in sync with the rise and fall of non-owner-occupied home purchases and the housing price cycle.

Credit conditions: We include several variables on credit conditions at the zip code level to control for the credit expansion during the recent housing boom. We use mortgages originated for home purchases and link the lender institutions on the HUD subprime home lender list to the HMDA data to identify the mortgages issued to the subprime households. As the HUD subprime home lender list ended in 2005, we use the fraction of subprime mortgage originations in 2005 as the share of low-quality loans in the zip code during the housing cycle. This fraction has a mean of $21.1 \%$ and a standard deviation of $13.8 \%$. The HMDA data set also indicates whether a mortgage application is denied by the lender, and whether the originated mortgage is sold to

\footnotetext{
${ }^{20}$ Authorization to start is a largely irreversible process, with housing starts being only $2.5 \%$ lower than building permits at the aggregate level according to https://www.census.gov/construction/nrc/nrcdatarelationships.html, the website of the Census Bureau. Moreover, the delay between authorization and housing start is relatively short, on average less than one month, according to https://www.census.gov/construction/nrc/lengthoftime.html. These facts suggest that building permits are an appropriate measure of new housing supply.

${ }^{21}$ Our results for new housing supply are robust to allocating new building permits at the county level to zip codes according to the fraction of employment in residential construction in 2000.
} 
government sponsored entities (GSEs). Consequently, we can also control for the mortgage denial rate and the share of mortgages sold to GSEs in 2005 at the zip code level. ${ }^{22}$ The mortgage denial rate has a mean of $13.9 \%$ and the fraction of GSE mortgages has a mean of $19.3 \% .{ }^{23}$ We also include the denial rate and the fraction of mortgages sold to GSEs for non-owner-occupied mortgages to control for the possible heterogeneous credit conditions to housing investors.

Other controls: For housing supply elasticity, we employ the widely used elasticity measure constructed by Saiz (2010). This measure reflects geographic constraints in home building by defining undevelopable land for construction as terrain with a slope of 15 degrees or more and as areas lost to bodies of water including seas, lakes, and wetlands. This measure has a lower value if an area is more geographically restricted. ${ }^{24}$

We also control for various economic fundamentals at the zip code level. We use information from the Census Bureau in 2000 including population, fraction of college-educated population, fraction of workforce, median household income, poverty rate, urban rate, and the fraction of white people. In addition, we control for whether a state is one of the so-called "sand states" (Arizona, California, Florida, and Nevada), and whether the state has non-recourse mortgage laws. As highlighted, for instance, by Nathanson and Zwick (2017) and Choi et al. (2016), the sand states experienced phenomenal housing cycles in comparison to the rest of the U.S. in such outcomes as mortgage origination, defaults, and housing price fluctuations. ${ }^{25}$ The nature of the mortgage laws in a given state has been found to be an important predictor of real outcomes in the housing market (Dobbie and Goldsmith-Pinkham (2014)) and of speculative activity in the housing market (Nam and $\mathrm{Oh}(2016))$.

\footnotetext{
${ }^{22}$ We control for these variables only in 2005 since we use the subprime mortgage fraction in 2005 . The results are unaffected if we instead choose these controls in 2004-2006.

${ }^{23} \mathrm{We}$ acknowledge that misreporting is common in mortgage data, as emphasized in Griffin and Maturana (2015, 2016). For example, recent studies such as Avery et al. (2012), Blackburn and Vermilyea (2012), and Mian and Sufi (2015), cast doubt on the accuracy of HMDA data, and, in particular, find that the income variable could be overstated by home buyers. For this reason, we use income data from the IRS and control for the misreporting measure from Piskorski, Seru, and Witkin (2015) for robustness.

${ }^{24}$ The Saiz (2010) measure is not, however, without its issues. Davidoff (2015), for instance, argues that the Saiz measure is a poor instrument for housing prices because it is correlated with many variables related to housing demand.

${ }^{25}$ In Section $\mathrm{G}$ of the Internet Appendix, we rerun all our regressions excluding the four sand states for robustness. It is reassuring that our results are not affected by their exclusion.
} 
In addition, we control for other potential sources of secondary housing demand beyond speculation. We collect the fraction of renters in a zip code, as well as the fraction of immigrants in the past five years, to control for long-term trends in local demographics. We also collect the fraction of employment in recreation and entertainment to proxy for the appeal of a zip code as a vacation destination. We construct these variables from the 2000 Census data. While it is infeasible to consider all potential confounding factors in our analysis, we believe that with theses controls, we provide an improvement over existing measures of housing speculation to systematically investigate its causal effects.

Note that the limitation of our sample is that Case Shiller housing price data requires a sufficient number of housing transactions within a zip code to be able to construct indices based on repeated sales of the same house. After including all these controls, our data sample covers 3,935 zip codes during the boom period and 3,904 zip codes during the bust period across the U.S.

Speculation vs subprime: Figure 6 shows that there is little correlation between the distribution of housing speculation and that of subprime mortgages across zip codes. Statistically, the correlation coefficient between the fraction of non-owner-occupied home purchases in 20042006 and the fraction of subprime mortgages in 2005 is only 0.004 and is insignificant. This suggests that housing speculation is a phenomenon largely independent of the credit expansion to subprime households. Instead, our measure of housing speculation captures the purchases of nonowner-occupied homes by relatively wealthier households in booming areas.

Panel B of Table 1 provides evidence of where non-owner occupied versus subprime housing purchases were prevalent during the boom period by examining their correlations with our controls. Although both occurred in areas with similar initial fundamentals in 2000, along demographic dimensions including the poverty rate, median household income, and employment, and were pronounced in the four sand states and areas that had higher housing price appreciation from 2003-2006 and mortgage denial rates in 2005, they differed along several substantive dimensions during the boom. Speculation occurred in areas that experienced economic expansions in income, payroll, and employment. Subprime credit expansion, in contrast, flourished in areas that experienced economic contractions, and that had inelastic housing supplies, non-recourse mortgage laws, and a lower fraction of GSE loans. 
Regression analysis: To account for the relative importance of different zip codes in the recent U.S. housing cycle, we conduct all our regression analyses by weighting observations by the number of households within the zip code in 2000. All our results are robust to employing an equal-weighting scheme instead. In addition, because our instrument varies across states, we cluster standard errors at the state level in all regressions. Although our tax instrument is at the state level, it nevertheless provides substantial cross-sectional variation for us to identify the effects of speculation during the recent U.S. housing cycle.

\section{Economic Consequences}

In this section, we examine the cross-section of housing speculation during the boom period of 2004-2006, and its economic consequences during both the boom period and the subsequent bust period of 2007-2009.

\section{A. Housing Cycle}

We first examine the link between housing speculation and the housing cycle. Figure 7 provides a scatter plot of the real housing price changes during the boom period of 2004-2006 (Panel A) and the bust period of 2007-2009 (Panel B) against the fraction of non-owner-occupied home purchases during the boom period of 2004-2006 at the zip code level. The plot displays a clear association between more intensive housing speculation and both greater housing price increases during the boom, and greater subsequent housing price collapses during the bust.

Table 3 reports the two-stage instrumental variable approach to formally analyze this relation by using the variable of the marginal capital gains tax rate for the median income household within the state as our instrument. Specifically, we first regress the fraction of non-owner-occupied home purchases during the boom period of 2004-2006 on the tax instrument:

$$
\text { Speculation }_{i, \text { boom }}=a+b \text { Tax }_{i}+\text { Controls }_{i}+\epsilon_{i},
$$

where we use a list of controls, including the supply elasticity measure, the fraction of subprime mortgages in 2005, the mortgage denial rate in 2005, the fraction of GSE mortgages in 2005, the mortgage denial rate for non-owner-occupied mortgages in 2005, the fraction of GSE mortgages 
for non-owner-occupied mortgages in 2005, per capita income change in 2003-2006, population change in 2003-2006, the change in the number of establishments in 2004-2006, real payroll change in 2004-2006, the employment change in 2004-2006, the natural logarithm of the population in 2000 , the fraction of the college educated in 2000 , the fraction of the employed in 2000 , the fraction of workforce in 2000 , median household income in 2000 , the poverty rate in 2000 , the urban rate in 2000, the fraction of white residents in 2000, the fraction of employment in arts, entertainment, and recreation in 2000, the fraction of renters in 2000, the fraction of immigrants in 2000, a dummy for whether a state has non-recourse mortgage laws, and a dummy for whether a state is a sand state.

Column (1) of Table 3 shows the first stage result that the tax instrument has a significant explanatory power for the fraction of non-owner-occupied home purchases. The F-statistic of 69.93 provides reassurance that the tax rate variable is a valid instrument, with regard to relevance, for the fraction of non-owner-occupied home purchases.

We next analyze the causal effect of housing speculation on price expansion during the boom period, and the price contraction during the bust period. Specifically, we regress cumulative changes in housing price in 2004-2006 and in 2007-2009 on the predicted fraction of non-owneroccupied home purchases during the boom period of 2004-2006, instrumented by our tax rate variable, following the first-stage regressions:

$$
\Delta \text { Price }_{i, \text { boom or bust }}=a+b \overline{\text { Speculation }_{i, b o o m}}+\text { Controls }_{i}+\epsilon_{i}
$$

where the left-hand variable is the housing price change during either the boom period of 20042006 or the bust period of 2007-2009, and $\overline{\text { Speculation }_{i, b o o m}}$ is the projected housing speculation from the first-stage regression. We also add the same control variables from the first stage regression.

Column (2) of Table 3 shows that the IV coefficient estimate of the impact of housing speculation on housing prices during the boom is significantly positive, both statistically and in its economic magnitude: a one standard deviation increase in the fraction of non-owner-occupied home purchases across zip codes causes a substantial price increase of $26.5 \%$. Column (3) of Table 3 shows the IV estimate of the impact of housing speculation on the housing price contraction 
during the bust is significantly negative, both statistically and in its economic magnitude: a one standard deviation increase in the fraction of non-owner-occupied home purchases across zip codes translates to a substantial price decline of $37.4 \%$. Taken together, our analysis establishes a causal link between housing speculation during the boom period of 2004-2006 and the housing boom and bust cycle of 2004-2009.

What drove housing speculation during the boom period? We now examine extrapolative expectations as a driver of housing speculation. We hypothesize that non-owner-occupied home purchases in areas with less capital gains taxation would anchor more strongly on lagged housing price changes, given that speculators with extrapolative expectations expect to profit more from housing speculation in these areas. To test this hypothesis, we run the following regression:

$$
\begin{aligned}
\text { Speculation }_{i, \text { boom }}= & a+b \Delta \text { Price }_{i, p r e-\text { boom }}+c \text { Tax }_{i}+d \Delta \text { Price }_{i, p r e-b o o m} \cdot \text { Tax }_{i}+ \\
& \text { Controls }_{i}+\epsilon_{i},
\end{aligned}
$$

where Speculation $_{i, \text { boom }}$ is the fraction of non-owner-occupied home purchases in zip code $i$ during the boom period of 2004-2006 and $\Delta$ Price $_{i, p r e-b o o m}$ refers to the cumulative housing price change during the pre-boom period of 2001-2003. We also interact $\Delta$ Price $_{i, p r e-b o o m}$ with the capital gains tax rate $\operatorname{Tax}_{i}$. Lastly, we also control for a host of local fundamental variables during the pre-boom period.

Table 4 displays the results on extrapolation. Without including the state capital gains tax rate, Column (1) shows positive though statistically insignificant relationship between housing speculation and the lagged housing price change. In contrast, when we introduce the state capital gains tax rate into the regression, as specified in equation (3). Column (2) shows that, across zip codes, housing price increase during the pre-boom period significantly predict higher fractions of non-owner-occupied home purchases during the boom period. More importantly, housing speculation at the zip code level in states with less capital gains taxes reacted more strongly to the pre-boom housing price increase, and this relation is statistically significant at the $1 \%$ level. ${ }^{26}$ This

\footnotetext{
${ }^{26}$ The Frisch Waugh Theorem gives an alternative interpretation of our results. The coefficient on past housing prices and its interaction with the tax instrument is equivalent to regressing the residual from regressing the fraction of nonowner-occupied home purchases on fundamentals on the residuals from regressing past housing prices and its
} 
finding thus provides evidence that housing speculation, anchored on past house price changes, contributed a non-fundamental source of housing demand during the boom, especially in areas more prone to speculative behavior. ${ }^{27}$ This result also indicates the important role played by state capital gains taxation in shaping speculators' extrapolative behavior, validating relevance of this instrument for our subsequent analysis.

\section{B. Economic Cycle}

By affecting housing prices, housing speculation can also impact local economic activity. We again apply the two-stage instrumental variable approach to formally analyze this relation by using the variable of the marginal capital gains tax rate for the median income household within a state as the instrument. For the second stage, we run the following regression:

$$
\Delta Y_{i, \text { boom or bust }}=a+b \overline{\text { Speculation }_{i, \text { boom }}}+\text { Controls }_{i}+\epsilon_{i} \text {, }
$$

where $\Delta Y_{i, \text { boom or bust }}$ indicates the cumulative change in economic outcomes (per capita income, the number of establishments, real payroll, and employment) during either the boom period of 2004-2006 or the bust period of 2007-2009, and $\overline{\text { Speculation }_{i, b o o m}}$ is the projected housing speculation from the first-stage regression specified in equation (1).

We first examine to what extent housing market speculation contributed to local economic expansions during the boom period. Table 5 Panel A reports the results from using the measures of economic activity during the boom period of 2004-2006 as the dependent variables. Housing speculation is positively associated with all these measures. Real payroll, as shown in column (3), is most heavily affected by local housing speculation during the boom: a one standard deviation increase in the fraction of non-owner-occupied home purchases across zip codes leads to a substantial increase of $13.7 \%$ in real payroll. Income per capita and employment, as shown in columns (1) and (4), also increase by $12.9 \%$ and $8.4 \%$, respectively. Finally, the change in the

\footnotetext{
interaction on fundamentals. The OLS coefficients therefore capture the responsiveness of non-fundamental housing demand to past housing price growth that is orthogonal to fundamentals, and its interaction with the tax instrument.

${ }^{27}$ Consistent with our results, Wheaton and Nechayev (2008) show that a regression forecasting housing price appreciation systematically underestimates the realized housing price growth between 1998 and 2005, and that these forecast errors are positively correlated with the percentage of home sales attributed to investors and second home buyers within a MSA.
} 
number of establishments, shown in column (2), is the most modest, although the effect is still economically meaningful: a one standard deviation increase in the fraction of non-owner-occupied home purchases across zip codes translates to an increase of $6.8 \%$ in the number of establishments.

Panel B of Table 5 reports the results of regressing our measures of economic activity in the bust period of 2007-2009 on the fraction of non-owner-occupied home purchases during the boom period of 2004-2006, instrumented by our tax rate variable. Housing speculation is negatively associated with all four measures of economic consequences at the $1 \%$ significance level during the bust. Among these measures, real payroll, which is shown in column (3), is most heavily affected by local housing speculation during the boom: a one standard deviation increase in the fraction of non-owner-occupied home purchases across zip codes corresponds to a substantial drop of $15.4 \%$ in real payroll. The same increase in housing speculation also corresponds to substantial drops of $7.8 \%$ in income per capita, $8.7 \%$ in the number of establishments, and $14.6 \%$ in employment, as shown in columns (1), (2), and (4), respectively. The variation across zip codes in their economic responses, consequently, reflects not only differences in the deterioration of local fundamentals and firm adjustment costs of employment, wages, and establishments, but also differences in exposure to housing speculation during the boom.

As shown in Tables 3 and 5, some of these control variables are also highly significant. In particular, the fraction of subprime mortgages in 2005 is significantly correlated with the magnitudes of the housing price boom and bust, as well as our four measures of the local economic downturn during the bust period, consistent with the findings of Mian and Sufi $(2009,2014)$.

In addition to the results presented here, we also report robustness analyses in the Internet Appendix. As two of the four sand states, Florida and Nevada, have no capital gains taxes, this raises a potential concern that the effect of housing speculation on the price increase during the boom, and decline during the bust, might be driven by these two states. Section G of the Internet Appendix invalidates this concern by repeating Tables 3 and 5 excluding the four sand states. Section F illustrates that our results are quantitatively similar, and remain significant, if we instead use Zillow housing price data. Section H shows that our results are robust after excluding control variables related to local economic performance during the boom period that are potentially correlated with speculation and endogenous to the housing cycle. Finally, Table C2 in Section C 
reports the OLS estimates of Tables 3 and 5. Our IV analyses reveal a consistent downward bias in the OLS estimates. This is consistent with investment home buyers reducing their demand as house prices increase, and consequently having a smaller impact on economic outcomes, as well as with a downward bias in our measure of speculation because of cash deals and bank misreporting.

\section{Transmission Mechanisms}

Having demonstrated a causal relationship between housing speculation during the boom period and the decline in local economic activity during the bust, we now investigate several potential transmission mechanisms by which housing speculation propagated to the real economy during 2007-2009.

\section{A. Supply Overhang}

By driving up housing demand, housing speculation may have boosted the supply side of the housing market during the boom. The increased housing supply would then overhang on the housing market and the local economy during the bust, as argued by Rognlie, Shleifer, and Simsek (2015). This effect implies that housing speculation during the boom has a stronger negative predictive power for economic outcomes in the construction sector than for the non-construction sector. To examine this supply overhang effect, we first examine the impact of housing speculation on housing supply. Given that the Census Bureau provides building permit data only at the county level, we carry out the analysis by aggregating non-owner-occupied home purchases and all other

controls to the county level. Figure 8 provides a scatter plot of the building permits in 2004-2006 relative to the number of housing units in 2000 — our measure of new housing supply — against the fraction of non-owner-occupied home purchases in the same period. The plot vividly illustrates a positive relation between housing speculation and new housing supply.

Table 6 then demonstrates a causal link by regressing the new housing supply measure on the fraction of non-owner-occupied home purchases in 2004-2006, instrumented by the state capital gains tax rate variable. We report the two-stage results in columns (1) and (2), from the regressions specified in equations (1) and (2), respectively. A difference from our previous analyses is that the observations in Table 6 are at the county level. We weight observations by the total number of 
households at the county level in 2000, and cluster standard errors at the state level. As shown in column (1), the tax instrument also has significant explanatory power for the fraction of nonowner-occupied home purchases at the county level. The F-statistic of 19.75 from the first stage suggests that the instrument is statistically strong for this county-level test. Column (2) reports the second-stage results. The IV coefficient estimate of the impact of housing speculation on the new supply during the boom is significantly positive, establishing a causal link between them. Specifically, a one standard deviation increase in the fraction of non-owner-occupied home purchases across counties corresponds to a substantial increase of $4.2 \%$ in new housing supply between 2004 and 2006.

We also expect stronger explanatory power for economic outcomes in the construction sector than other sectors during the boom period. We examine this effect by returning to a zip code-level and Panel A of Table 7 confirms this hypothesis. Housing speculation drove the increase in employment in the construction sector more dramatically than that in other sectors: a one standard deviation increase in the fraction of non-owner-occupied home purchases across zip codes corresponds to an increase of $25.1 \%$ in employment in the construction sector (Column 1 ) and of $6.1 \%$ in other industries (Column 2). The statistically and economically significant impact of housing speculation on industries other than the construction sector, however, suggests that additional transmission mechanisms are needed to explain the overall economic effect of housing speculation.

Supply overhang can both exacerbate the subsequent housing price bust and reduce demand for new housing, leading to a large decline in construction activity during the recession. The impact could be even more pronounced than that in the boom since construction is irreversible. We examine this effect by returning to a zip code-level analysis of economic performance of different sectors during the bust period using the same two-stage regressions as in Panel B of Table 7. Column (1) shows that housing speculation leads to a severe reduction in employment in the construction sector. Consistent with the supply overhang channel, the IV coefficient estimate shows that the impact of housing speculation on the construction sector is more than twice as great as that on total employment (reported in Panel B of Table 5) - a one standard deviation increase in the fraction of non-owner-occupied home purchases across zip codes during the boom is associated with a decrease of $33.8 \%$ in construction-sector employment during the bust. 
In column (2), we also examine the change in employment in all industries except the construction sector. The result is still both statistically and economically significant: A one standard deviation increase in the fraction of non-owner-occupied home purchases across zip codes causes a decrease of $12.4 \%$ in non-construction sector employment. This result suggests that the economic effects of housing speculation are not restricted to the construction sector.

\section{B. Local Demand}

We also examine an alternative channel for housing speculation to affect the real economy through local demand. Housing speculation may have exacerbated the fluctuations in household wealth during the housing boom and bust, which may affect their consumption. As suggested by Mian, Rao, and Sufi (2013) and Mian and Sufi (2014), the shock to household consumption would, in turn, drive the demand for local services. Thus, housing speculation during the boom may also lead to an economic cycle through this local demand channel. As such, we expect housing speculation during the boom to have stronger explanatory power for economic outcomes in industries that are driven by local demand.

To examine this local demand channel, we use the classification of non-tradable and tradable industries from Mian and Sufi (2014), ${ }^{28}$ who define these sectors based on an industry's geographical concentration. Since non-tradable sectors service local demand within a region, their locations tend to be dispersed geographically. In contrast, tradable sectors supply goods to meet national demand and are less exposed to local economic conditions, and therefore they should be more concentrated spatially to take advantage of economic scale and specific resources. As an alternative, we also examine the restaurant and retail sectors more narrowly, which mainly rely on local demand.

Table 8 reports the coefficient estimates from the regression of the fraction of non-owneroccupied home purchases during the boom period on the change in employment in the non-tradable sectors in column (1), and the retail and restaurant sectors in column (3), during both the boom (Panel A) and the bust (Panel B) periods using our IV method. Housing speculation has an economically profound impact on employment in these sectors at the $1 \%$ significance level: an

\footnotetext{
${ }^{28}$ For the detailed classification, refer to Appendix Table 1 of Mian and Sufi (2014).
} 
increase of one standard deviation in the share of non-owner-occupied home purchases in 20042006 is associated with an increase of $8.8 \%$ (a decrease of 15.1\%) in the employment of nontradable sectors, and of $8.9 \%$ (15.6\%) in the employment of retail and restaurant sectors in 20042006 (2007-2009). These economic magnitudes are similar to those for the change in overall employment, reported in column (4) of Table 5, and for the change in non-construction employment, reported in column (2) of Table 7. This sizable effect on the non-tradable sectors, whether broadly or narrowly defined, indicates that housing speculation during the housing boom had a substantially adverse effect on local demand during the housing bust.

For comparison, we also include the estimates for the employment change in tradable industries in column (2) and the employment change in industries other than retail and the restaurant business in column (4). Housing speculation has an insignificant effect on the employment of tradable industries and on industries other than retail and the restaurant business during the boom period. During the bust period, we also find an insignificant impact on the employment of tradable sectors, and that the impact of housing speculation on the retail and restaurant business was stronger than that on the other sectors $(15.6 \%$ versus $11.2 \%$ from a onestandard-deviation increase in housing speculation). As employment in tradable sectors relies more on national demand, the adverse effects of local housing speculation are weaker for these industries.

Taken together, our analysis provides evidence that housing speculation affected real economic outcomes during the Great Recession through the supply overhang and the local demand channels. Since employment in residential construction contributes to local demand, these two channels are likely complementary, and it is reassuring that we find that both are significant in contributing to the severity of the local recessions during the bust. ${ }^{29}$

\footnotetext{
${ }^{29}$ While we focus on only two channels, the literature has identified several other potential transmission mechanisms. By reducing the collateral value of housing (a widely-used collateral for firms to raise debt financing), housing speculation may have affected firms' access to credit during the housing bust, as studied in Adelino, Schoar, and Severino (2015) and Schmalz, Sraer, and Thesmar (2017). Another channel is through the impairment of intermediary balance sheets of local banks during the bust, which may have prevented them from lending to local firms, as highlighted in Gan (2007) and He and Krishnamurthy (2013). Housing speculation may also affect local economic activity through a crowding out effect. By encumbering mortgage financing from local banks, housing speculation may have crowded out limited bank financing to non-housing investment, as suggested by Chakraborty, Goldstein and MacKinlay (2018). We leave it to future research to analyze these potentially important channels.
} 


\section{Conclusion}

In this paper, we provide evidence that housing speculation, as measured by the fraction of non-owner-occupied home purchases, arose from extrapolation by speculators of past housing price changes. We document how this speculation during the boom period of 2004-2006 had positive economic consequences during the boom period, and adverse consequences during the bust period of 2007-2009. We demonstrate this causal relationship by taking advantage of an instrument based on variation in state capital gains taxation. Our results suggest that housing speculation had real economic consequences during the boom, by increasing housing prices and fueling local economic expansions, and during the recession, by depressing residential construction employment, as a result of supply overhang, and by reducing local household demand. Taken together, our analysis reveals that speculation in housing markets, partly driven by behavioral biases, impacted the real economy both during and in the aftermath of the recent U.S. housing cycle.

\section{References}

Albanesi, Stefania, Giacomo De Giorgi, and Jaromir Nosal (2017), Credit Growth and the Financial Crisis: A New Narrative, mimeo University of Pittsburgh, Geneva School of Economics and Management, and Boston College.

Adelino, Manuel, Antoinette Schoar, and Felipe Severino (2015). House Prices, Collateral, and Self-employment. Journal of Financial Economics 117(2), 288-306.

Avery, Robert, Neil Bhutta, Kenneth Brevoort, and Glenn Canner (2012), The Mortgage Market in 2011: Highlights from Data Reported under the Home Mortgage Disclosure Act, Federal Reserve Bulletin 98(6): 1-46.

Bailey, Michael, Ruiqing Cao, Theresa Kuchler, and Johannes Stroebel (2017), The Economic Effects of Social Networks: Evidence from the Housing Market, Journal of Political Economy, forthcoming.

Barlevy, Gadi and Jonas D.M. Fisher (2011), Mortgage Choice and Housing Speculation, mimeo Federal Reserve Bank of Chicago.

Bayer, Patrick, Christopher Geissler, Kyle Mangum, and James W. Roberts (2015), Speculators

and Middlemen: The Strategy and Performance of Investors in the Housing Market, mimeo Duke University, Georgia State University, ISO New England, and NBER.

Blackburn, McKinley and Todd Vermilyea (2012), The Prevalence and Impact of Misstated Incomes on Mortgage Loan Applications, Journal of Housing Economics 21: 151-168. 
Case, Karl and Robert J. Shiller (2003), Is There a Bubble in the Housing Market?, Brookings Papers on Economic Activity 2003(2): 299-362.

Case, Karl, Robert J. Shiller, and Anne Thompson (2012), What Have They Been Thinking? Homebuyer Behavior in Hot and Cold Markets. Brookings Papers on Economic Activity, 265-315. Case, Karl, Robert J. Shiller, and Anne Thompson (2015), What Have They Been Thinking? Homebuyer Behavior in Hot and Cold Markets - A 2014 Update, Cowles Foundation Discussion Paper.

Chakraborty, Indraneel, Itay Goldstein, and Andrew MacKinlay (2018), Housing Price Booms and Crowding-Out Effects in Bank Lending, Review of Financial Studies 31(7): 2806-2853.

Charles, Kerwin Kofi, Erik Hurst, and Matthew J. Notowidigdo (2016a), Housing Booms and Busts, Labor Market Opportunities, and College Attendance, mimeo University of Chicago and Northwestern.

Charles, Kerwin Kofi, Erik Hurst, and Matthew J. Notowidigdo (2016b), Housing Booms, Manufacturing Decline, and Labor Market Outcomes, mimeo University of Chicago and Northwestern.

Chen, Ting, Laura Xiaolei Liu, Wei Xiong, Li-An Zhou (2016), The Speculation Channel and Crowding Out Channel: Real Estate Shocks and Corporate Investment in China, mimeo Princeton University.

Cheng, Ing-haw, Sahil Raina, and Wei Xiong (2014), Wall Street and the Housing Bubble, American Economic Review 104, 2797-2829.

Chinco, Alex and Christopher Mayer (2016), Misinformed Speculators and Mispricing in the Housing Market. Review of Financial Studies 29(2): 486-522.

Choi, Hyun-Soo, Harrison Hong, Jeffrey D. Kubik, and Jeffrey P. Thompson (2016), Sand States and the U.S. Housing Crisis, mimeo Singapore School of Management, Columbia University, Syracuse University, and Federal Reserve Board.

Da, Zhi, Mitch Warachka, and Hayong Yun (2016), Fiscal Policy, Consumption Risk, and Stock Returns: Evidence from U.S. States, mimeo University of Notre Dame, University of San Diego, and Michigan State University.

Davidoff, Thomas (2015), Supply Constraints Are Not Valid Instrumental Variables for Home Prices Because They Are Correlated with Many Demand Factors, mimeo UBC.

DeFusco, Anthony A., Charles G. Nathanson, and Eric Zwick (2017), Speculative Dynamics of Prices and Volume, mimeo Kellogg School of Management and University of Chicago Booth.

Dobbie, Will, and Paul Goldsmith-Pinkham (2014), Debtor protections and the Great Recession, Working paper.

Fajgelbaum, Pablo D., Eduardo Morales, Juan Carlos Suarez Serrato, and Owen M. Zidar (2018), State Taxes and Spatial Misallocation. Review of Economic Studies, Forthcoming.

Favara, Giovanni, and Jean Imbs (2015). Credit Supply and the Price of Housing. American Economic Review, 105(3), 958-992.

Favilukis, Jack, Sydney Ludvigson, and Stijn Van Nieuwerburgh (2015), Macroeconomic Implications of Housing Wealth, Housing Finance, and Limited Risk-Sharing in General Equilibrium, Journal of Political Economy, forthcoming. 
Ferreira, Fernando, and Joseph Gyourko (2018), Anatomy of the Beginning of the Housing Boom: US Neighborhoods and Metropolitan Areas, mimeo NBER.

Gale, William G., Aaron Krupkin, and Kim Reuben (2015), The Relationship between Taxes and Growth at the State Level: New Evidence, mimeo Brookings Institute.

Gan, Jie (2007), The Real Effects of Asset Market Bubbles: Loan- and Firm-level Evidence of a Lending Channel. Review of Financial Studies 20(6), 1941-1973.

Glaeser, Edward (2013), A Nation of Gamblers: Real Estate Speculation and American History, American Economic Review Papers and Proceedings 103(3), 1-42.

Glaeser, Edward, Joseph Gyourko, and Albert Saiz (2008), Housing Supply and Housing Bubbles, Journal of Urban Economics 64, 198-217.

Glaeser, Edward and Charles G. Nathanson (2017), An Extrapolative Model of House Price Dynamics, Journal of Financial Economics, forthcoming.

Griffin, John M., and Gonzalo Maturana (2016), Who Facilitated Misreporting in Securitized Loans? Review of Financial Studies 29, 384-419.

Griffin, John M., and Gonzalo Maturana (2015), Did Dubious Mortgage Origination Practices Distort House Prices? Review of Financial Studies, forthcoming.

Haughwout, Andrew, Donghoon Lee, Joseph Tracy, and Wilbert van der Klaauw (2011), Real Estate Investors, the Leverage Cycle, and the Housing Market Crisis, Federal Reserve Bank of New York Staff Reports 514.

Haughwout, Andrew, Richard Peach, John Sporn, and Joseph Tracy (2013), The Supply Side of the Housing Boom and Bust of the 2000s, in Housing and the Financial Crisis, pp. 69-104, University of Chicago Press.

He, Zhiguo, and Arvind Krishnamurthy (2013). Intermediary Asset Pricing, American Economic Review 103, 732-770.

Himmelberg, Charles, Christopher Mayer, and Todd Sinai (2005), Assessing High House Prices: Bubbles, Fundamentals, and Misperceptions, Journal of Economic Perspectives 19 (4), 67-92.

Hurst, Erik, Benjamin J. Keys, Amit Seru, and Joseph S. Vavra (2016), Regional redistribution through the US mortgage market, American Economic Review 106(10), 2982-3028.

Justiano, Alejandro, Georgio Primiceri, and Andrea Tambolatti (2017), Credit Supply and the Housing Boom, mimeo Federal Reserve Bank of Chicago and Northwestern University.

Kaplan, Greg, Kurt Mitman, and Giovanni L. Violante (2017), The Housing Boom and Bust: Model Meets Evidence, mimeo University of Chicago, Stockholm University, and Princeton University.

Keys, Benjamin J., Tanmoy Mukherjee, Amit Seru, and Vikrant Vig (2009), Financial Regulation and Securitization: Evidence from Subprime Mortgage Loans, Journal of Monetary Economics 56 (5), 700-720.

Keys, Benjamin J., Tanmoy Mukherjee, Amit Seru, and Vikrant Vig (2010), Did Securitization Lead to Lax Screening? Evidence from Subprime Loans. The Quarterly Journal of Economics 125(1): 307-362.

Landvoigt, Tim, Monika Piazzesi, and Martin Schneider (2015), The Housing Market (s) of San Diego. American Economic Review 105.4, 1371-1407. 
Mayer, Christopher (2011), Housing Bubbes: A Survey, Annual Review of Economics 3, 559-577. Mayer, Christopher and Todd Sinai (2009), U.S. House Price Dynamics and Behavioral Finance," in Christopher L. Foote, Lorenz Goette and Stephan Meier, eds., Policy Making Insights from Behavioral Economics. Boston, Mass: Federal Reserve Bank of Boston, Ch. 5.

Mian, Atif, Kamalesh Rao, and Amir Sufi (2013), Household Balance Sheets, Consumption, and the Economic Slump, Quarterly Journal of Economics, 128(4), 1687-1726.

Mian, Atif and Amir Sufi (2009), The Consequences of Mortgage Credit Expansion: Evidence from the U.S. Mortgage Default Crisis, Quarterly Journal of Economics 124, 1449-1496.

Mian, Atif and Amir Sufi (2010), Household Leverage and the Recession of 2007-09, IMF Economic Review, 58, 74-117.

Mian, Atif and Amir Sufi (2011), House Prices, Home Equity-Based Borrowing, and the US Household Leverage Crisis, American Economic Review 101, 2132-2156.

Mian, Atif and Amir Sufi (2014), What Explains the 2007-2009 Drop in Employment? Econometrica 82(6), 2197-2223.

Mian, Atif and Amir Sufi (2015), Fraudulent Income Oversight on Mortgage Applications During the Credit Expansion of 2002 to 2005, mimeo University of Chicago and Princeton University.

Mian, Atif, Amir Sufi, and Francesco Trebbi (2015). Foreclosures, House Prices, and the Real Economy, Journal of Finance 70(6), 2587-2634.

Nathanson, Charles and Eric Zwick (2017), Arrested Development: Theory and Evidence of Supply-side Speculation in the Housing Market, mimeo, University of Chicago and Northwestern University.

Nam, Tong Yob and Seungjoon Oh (2016), Non-recourse Mortgage Law and Housing Speculation, mimeo OCC and Peking University.

National Association of Realtors (2015), Investment and Vacation Home Buyers Survey 2015.

Piazzesi, Monika and Martin Schneider (2009), Momentum Traders in the Housing Market: Survey Evidence and a Search Model, American Economic Review Papers and Proceedings 99(2), 406-411.

Piskorski, Tomasz, Amit Seru, and James Witkin (2015), Asset Quality Misrepresentation by Financial Intermediaries: Evidence from the RMBS Market, Journal of Finance, 70(6), 26352678.

Purnanandam, Amiyatosh (2011), Originate-to-distribute Model and the Subprime Mortgage Crisis, Review of Financial Studies 24, 1881-1915.

Rognlie, Matthew, Andrei Shleifer, and Alp Simsek (2015), Investment Hangover and the Great Recession, Working paper.

Saiz, Albert (2010), The Geographic Determinants of Housing Supply, Quarterly Journal of Economics 125(3), 1253-1296.

Schmalz, Martin C., David Alexandre Sraer, and David Thesmar (2017), Housing Collateral and Entrepreneurship, Journal of Finance, 72(1), 99-132.

Serrato, Juan Carlos Suárez, and Owen Zidar (2018), The Structure of State Corporate Taxation and its Impact on State Tax Revenues and Economic Activity, Journal of Public Economics 167, 158-176 
Shan, Hui (2011), The Effect of Capital Gains Taxation on Home Sales: Evidence from the Taxpayer Relief Act of 1997, Journal of Public Economics 95(1-2), 177-188.

Shiller, Robert (2009), Unlearned Lessons from the Housing Bubble, Economics Voice 6, 6.

Soo, Cindy K. (2018). Quantifying Sentiment with News Media across Local Housing Markets. Review of Financial Studies, 31(10), 3689-3719.

Stumpner, Sebastian (2016), Trade and the Geographic Spread of the Great Recession, Working Paper.

Walden, Michael L. (2014), Recovery from the Great Recession: Explaining Differences among States, Journal of Regional and Policy Analysis 44, 166-174.

Wheaton, William and Gleb Nechayev (2008), The 1998-2005 Housing "Bubble" and the Current "Correction": What's Different This Time?, Journal of Real Estate Research 30, 1-26. 


\section{Figure 1: Fraction of Non-Owner-Occupied Home Purchases}

This figure plots the share of non-owner-occupied home purchases for the U.S. and three cities, New York, Las Vegas, and Charlotte. The fraction of non-owner-occupied home purchases in each city is computed from the "Home Mortgage Disclosure Act" data set.

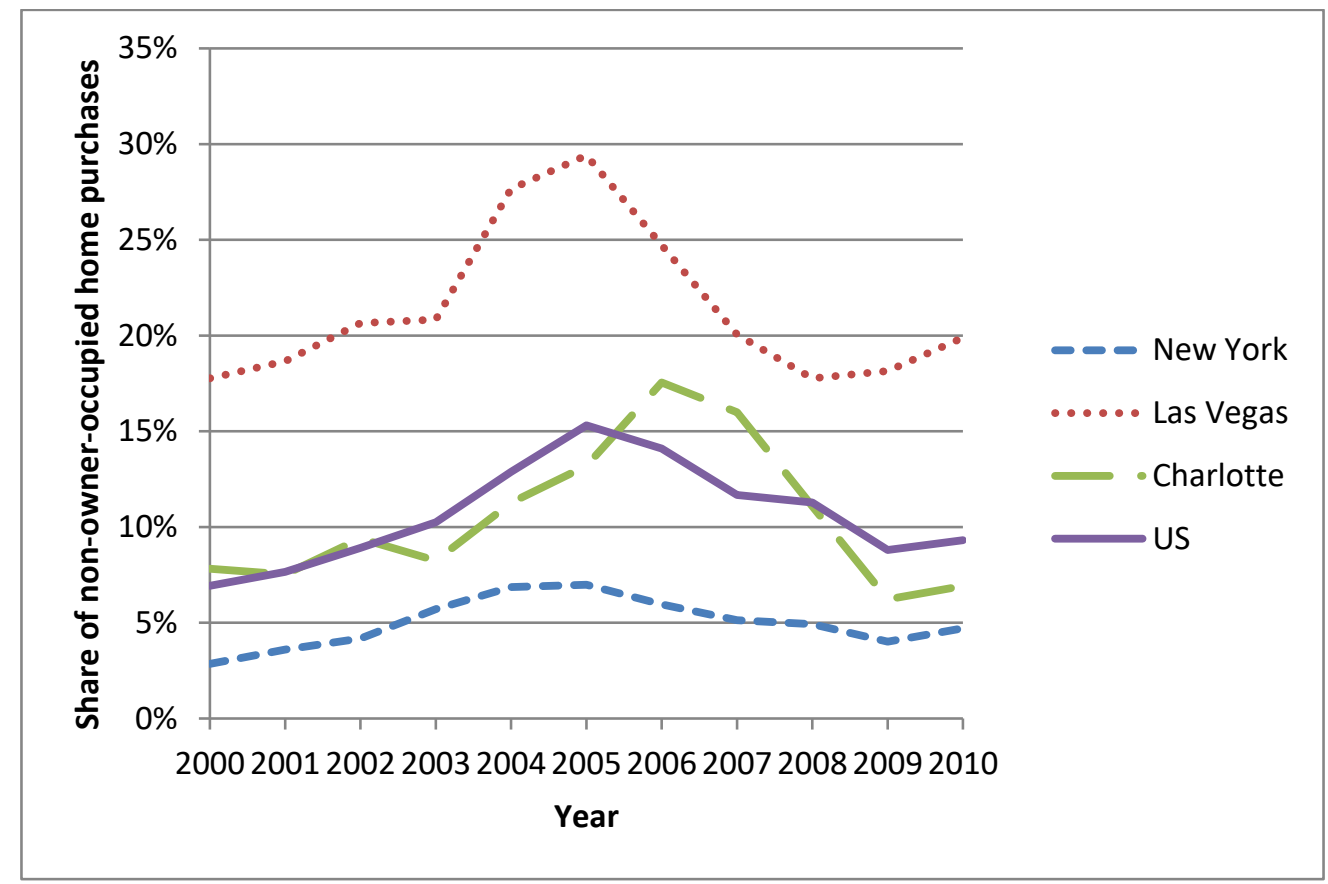

Figure 2: Distribution of Capital Gains Tax across U.S. States

This figure plots the map of the marginal state tax rates on capital gains for state median income in 2005 across U.S. states.

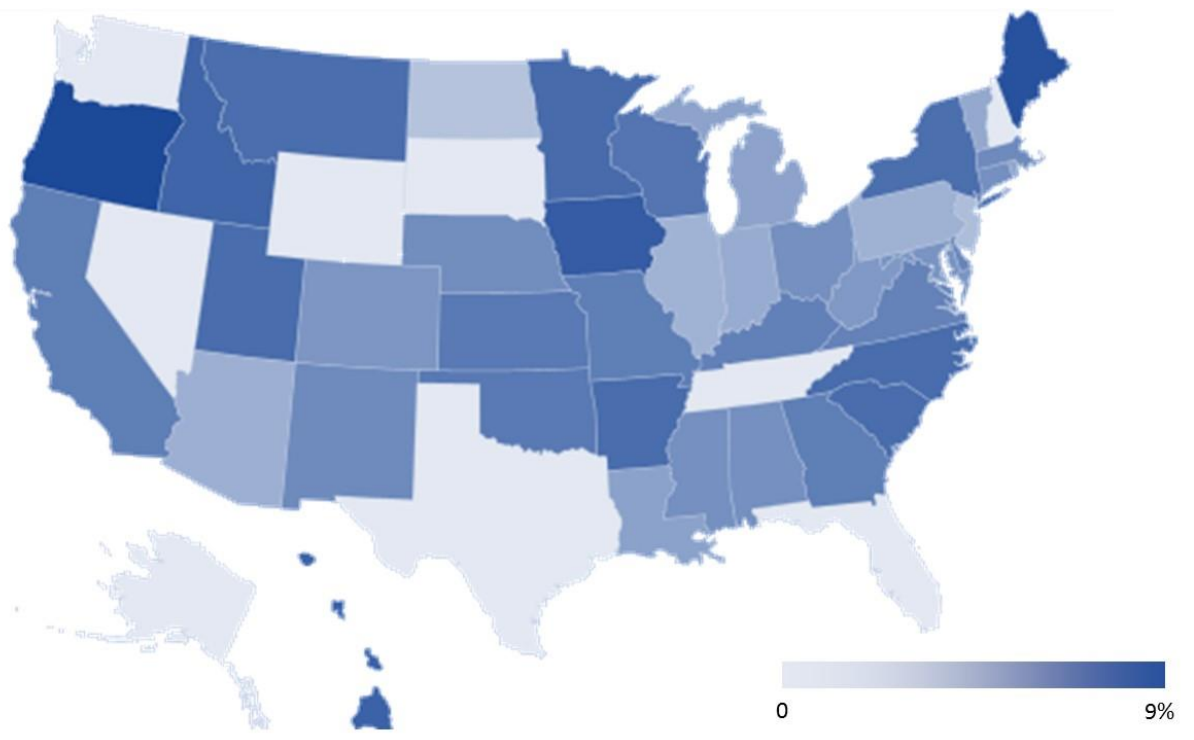




\section{Figure 3: Zip codes near borders of states without capital gains taxes}

This figure plots the fraction of non-owner-occupied home purchases in 2004-06 (Panel A) and the fraction of subprime mortgages in 2005 (Panel B) in zip codes near borders of states without capital gains taxes. The variables of interests are regressed on dummies indicating each one mile distance from the border (dummies are negative for neighboring states with capital gains taxes) and state-border*10-mile strip fixed effects. The figure plots the coefficients on the distance dummies.

Panel A: Non-owner-occupied home purchases

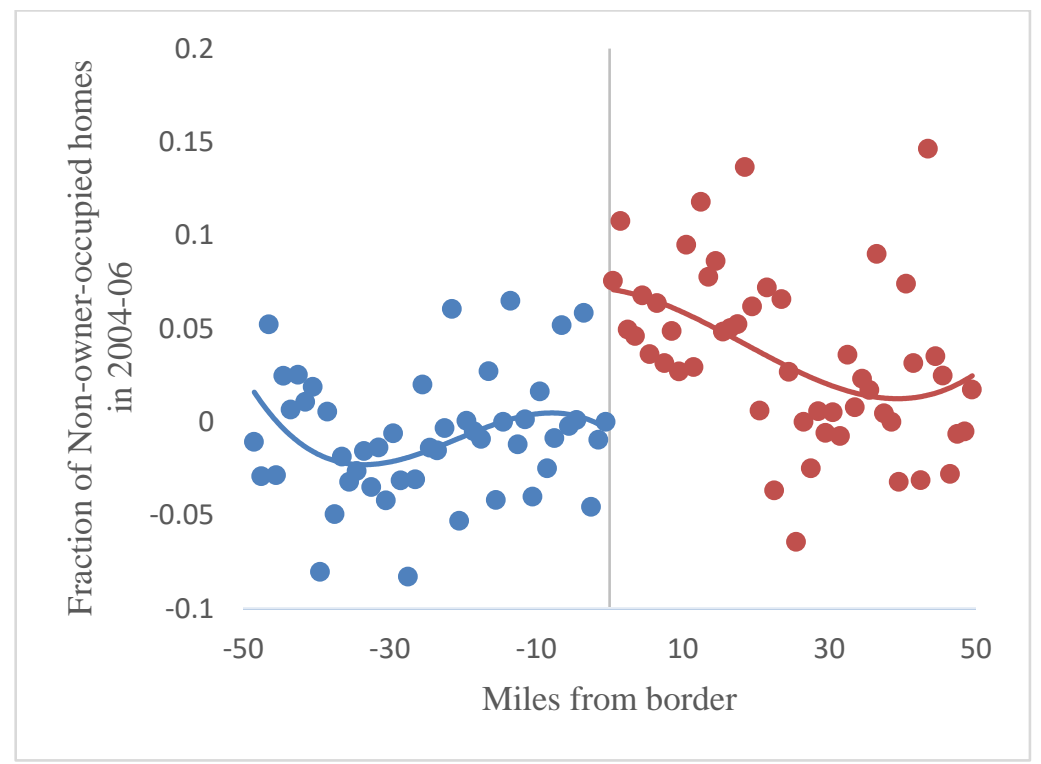

Panel B: Subprime mortgages

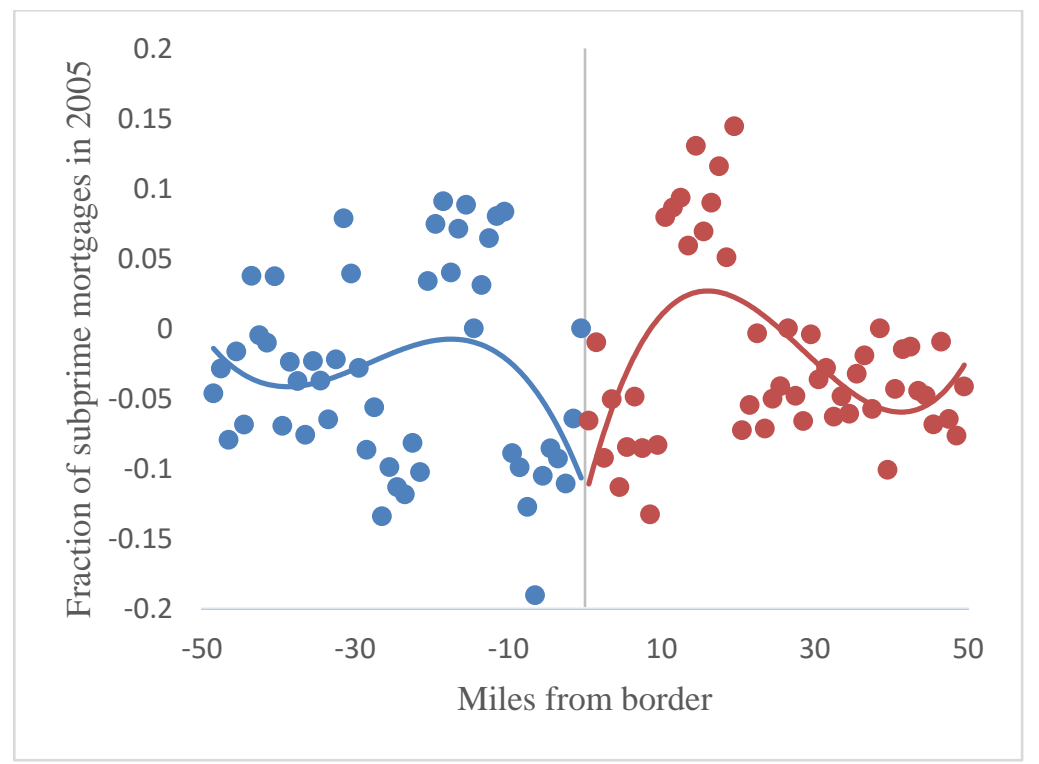




\section{Figure 4: Case-Shiller Home Price Indices}

This figure plots the Case-Shiller home price indices for the U.S. and three cities, New York, Las Vegas, and Charlotte. The price index is deflated by the CPI and normalized to 100 in 2000.

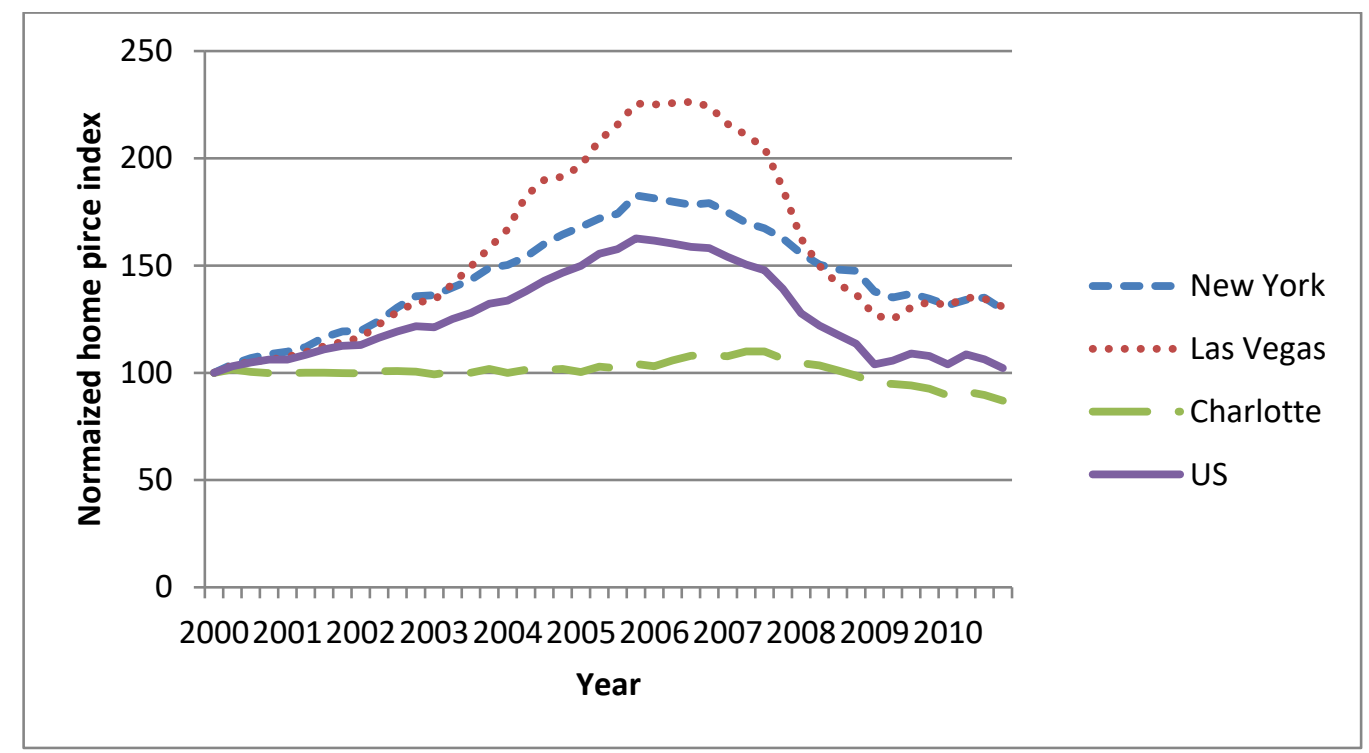

Figure 5: New Housing Supply

This figure depicts building permits in 2000 to 2010 relative to the housing units in 2000 for the U.S. and three cities, New York, Las Vegas, and Charlotte.

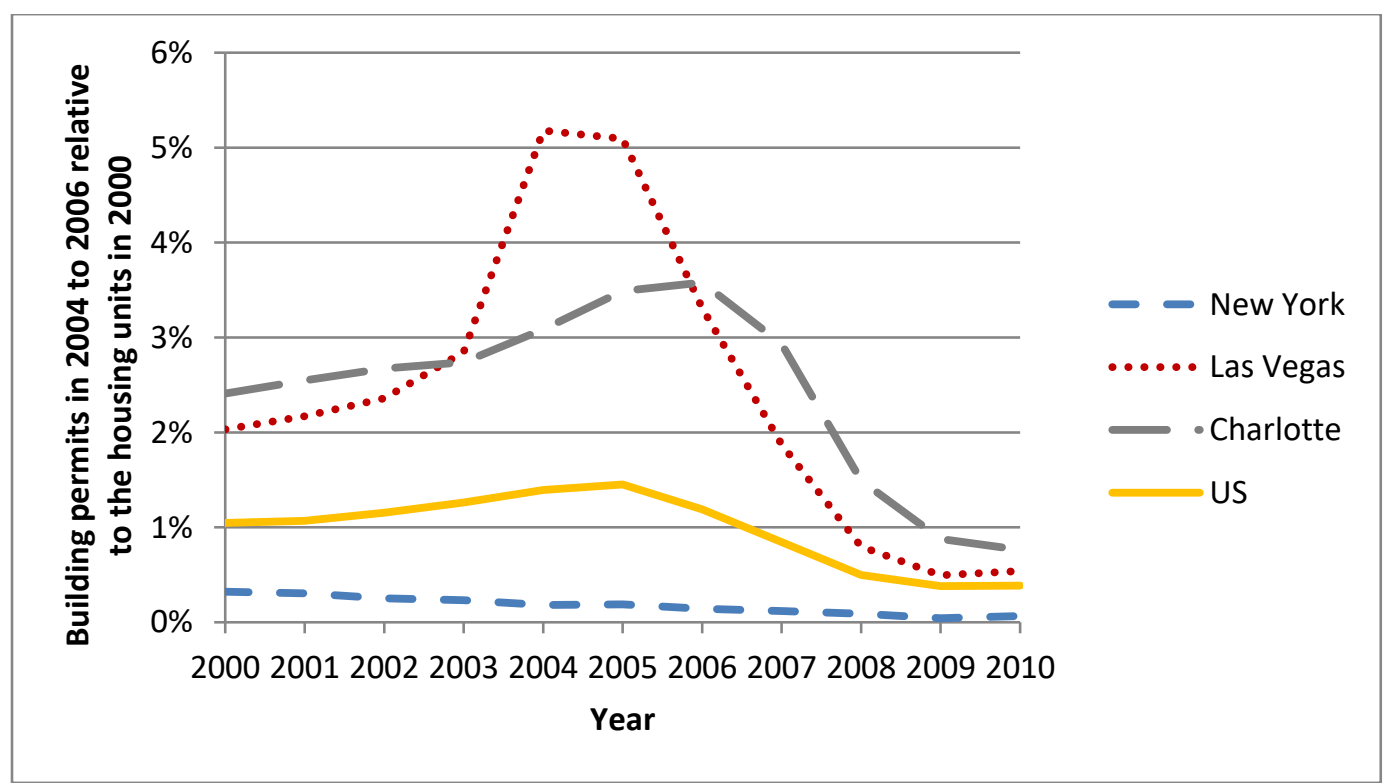




\section{Figure 6: Speculation and Subprime Households}

This figure plots the fraction of non-owner-occupied home purchases in 2004 to 2006 against the fraction of subprime mortgages in 2005 at the zip code level.

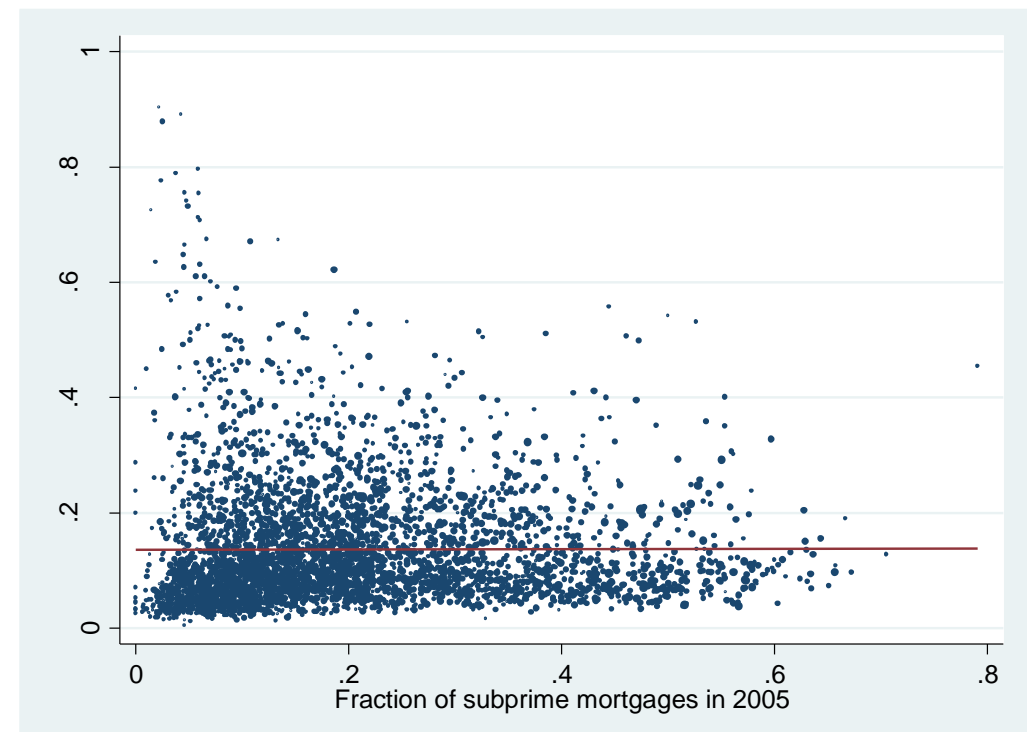

Figure 7: Speculation and Housing Price Cycle

These figures plot the real housing price change during the boom period of 2004 to 2006 (Panel A) and the bust period of 2007 to 2009 (Panel B) against the fraction of non-owner-occupied home purchases in 2004 to 2006 at the zip code level.

\section{Panel A:}

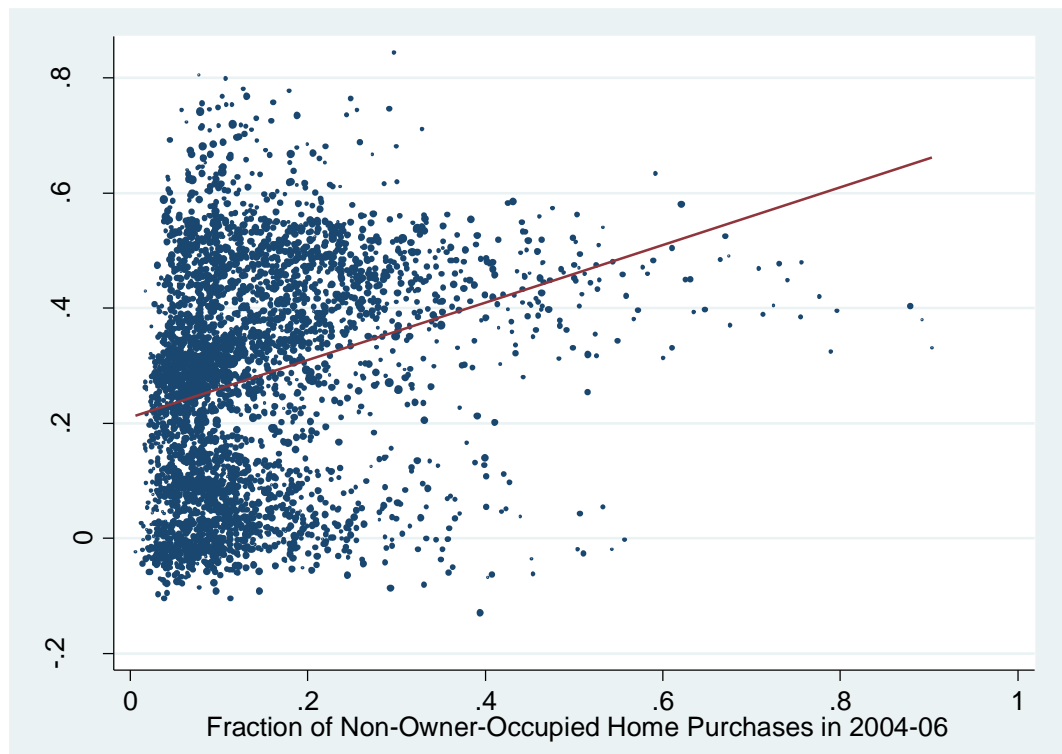




\section{Panel B:}

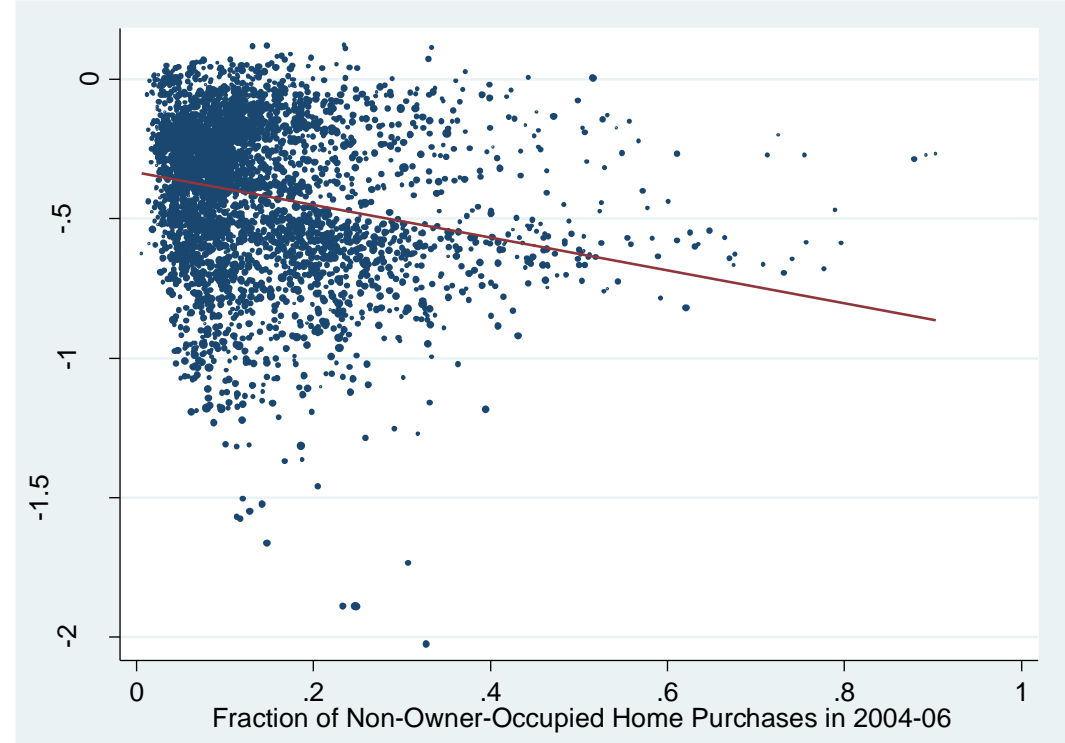

Figure 8: Speculation and New Housing Supply

This figure plots building permits in 2004 to 2006 relative to the number of housing units in 2000 against the fraction of non-owner-occupied home purchases in 2004 to 2006 at the county level.

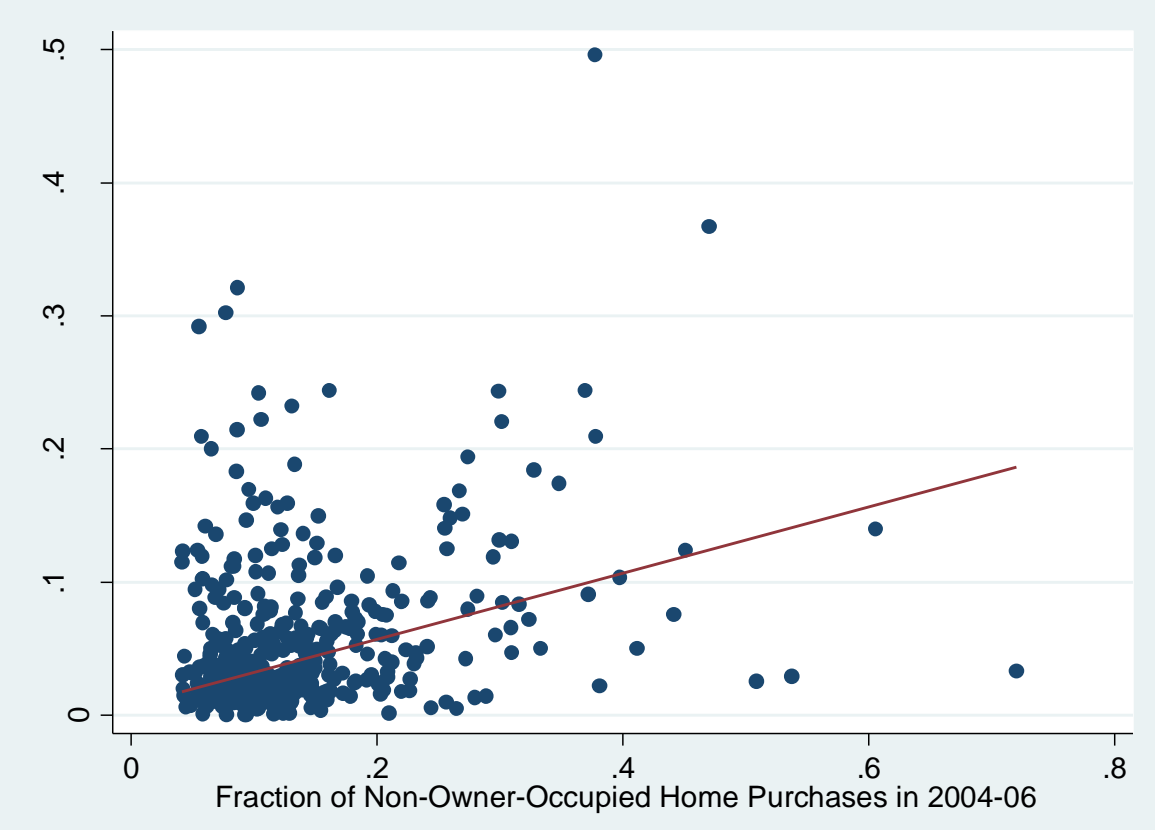


Table 1 Summary Statistics and Correlations

Panel A: Summary statistics of the key variables

\begin{tabular}{lccc}
\hline & $(1)$ & $(2)$ & $(3)$ \\
VARIABLES & $\mathrm{N}$ & Mean & Sd \\
\hline & & & \\
Fraction of Non-Owner-Occupied Home Purchases in 2004-06 & 3,975 & 0.136 & 0.0987 \\
Real house price change in 2001-03 & 4,027 & 0.191 & 0.135 \\
Real house price change in 2004-06 & 4,027 & 0.278 & 0.191 \\
Real house price change in 2007-09 & 4,027 & -0.413 & 0.278 \\
Per capita income change in 2003-06 & 4,027 & 0.0521 & 0.125 \\
Per capita income change in 2007-09 & 4,026 & -0.113 & 0.0957 \\
Change in no. of establishments in 2004-06 & 3,942 & 0.0638 & 0.0870 \\
Change in no. of establishments in 2007-09 & 3,924 & -0.0382 & 0.0706 \\
Real payroll change in 2004-06 & 3,942 & 0.0866 & 0.179 \\
Real payroll change in 2007-09 & 3,924 & -0.0998 & 0.191 \\
Employment change in 2004-06 & 3,942 & 0.0707 & 0.158 \\
Employment change in 2007-09 & 3,924 & -0.0831 & 0.148 \\
Saiz's elasticity & 4,027 & 1.376 & 0.715 \\
Fraction of subprime mortgages in 2002 & 3,468 & 0.0896 & 0.0725 \\
Fraction of subprime mortgages in 2005 & 3,975 & 0.211 & 0.138 \\
Mortgage denial rate in 2002 & 3,468 & 0.111 & 0.0573 \\
Mortgage denial rate in 2005 & 3,975 & 0.139 & 0.0507 \\
Non-owner-occupied home mortgage denial rate in 2002 & 3,414 & 0.115 & 0.0956 \\
Non-owner-occupied home mortgage denial rate in 2005 & 3,939 & 0.130 & 0.0637 \\
Fraction of GSE mortgages in 2002 & 3,468 & 0.376 & 0.113 \\
Fraction of GSE mortgages in 2005 & 3,975 & 0.193 & 0.103 \\
Fraction of GSE mortgages for non-owner-occupied home in 2002 & 3,388 & 0.383 & 0.170 \\
Fraction of GSE mortgages for non-owner-occupied home in 2005 & 3,935 & 0.181 & 0.114 \\
Ln of population in 2000 & 4,027 & 10.32 & 0.572 \\
Fraction of the college educated in 2000 & 4,027 & 28.12 & 15.63 \\
Fraction of the employed in 2000 & 4,027 & 61.14 & 8.782 \\
Fraction of workforce in 2000 & 4,027 & 64.70 & 8.106 \\
Median household Income in 2000 & 4,027 & 49,524 & 17,274 \\
Poverty rate in 2000 & 4,027 & 10.77 & 7.713 \\
Urban rate in 2000 & 4,027 & 94.30 & 14.21 \\
Fraction of the white in 2000 & 4,027 & 71.89 & 23.05 \\
Number of households in 2000 & 4,027 & 12,935 & 6,235 \\
Fraction of renters in 2000 & 3,942 & 0.355 & 0.964 \\
Fraction of immigrants in past 5 years (2000) & 3,942 & 0.214 & 0.0703 \\
Fraction of employment in arts entertainment and recreation in 2000 & 3,942 & 0.0832 & 0.0419 \\
\hline
\end{tabular}


Panel B: Correlations of non-owner-occupied versus subprime housing purchases with control variables during the boom period and the p-values of their differences

\begin{tabular}{|c|c|c|c|}
\hline VARIABLES & $\begin{array}{l}\text { Fraction of Non-Owner-Occupied } \\
\text { Home Purchases in 2004-06 }\end{array}$ & $\begin{array}{l}\text { Fraction of subprime } \\
\text { mortgages in } 2005\end{array}$ & $\begin{array}{c}\mathrm{p}- \\
\text { value }\end{array}$ \\
\hline $\begin{array}{l}\text { Real house price change in } \\
2004-06\end{array}$ & $0.277 * * *$ & $0.383 * * *$ & 0.000 \\
\hline $\begin{array}{l}\text { Per capita income change in } \\
2003-06\end{array}$ & $0.206 * * *$ & $-0.388 * * *$ & 0.000 \\
\hline $\begin{array}{l}\text { Change in no. of } \\
\text { establishments in 2004-06 }\end{array}$ & $0.100 * * *$ & $-0.066 * * *$ & 0.000 \\
\hline $\begin{array}{l}\text { Real payroll change in } 2004- \\
06\end{array}$ & $0.105 * * *$ & $-0.035^{*}$ & 0.000 \\
\hline $\begin{array}{l}\text { Employment change in 2004- } \\
06\end{array}$ & $0.061 * * *$ & $-0.041 * *$ & 0.000 \\
\hline Mortgage denial rate in 2005 & $0.199 * * *$ & $0.704 * * *$ & 0.000 \\
\hline $\begin{array}{l}\text { Fraction of GSE mortgages in } \\
2005\end{array}$ & -0.015 & $-0.564 * * *$ & 0.000 \\
\hline $\begin{array}{l}\text { Non-owner-occupied home } \\
\text { mortgage denial rate in } 2005\end{array}$ & $0.199 * * *$ & $0.389 * * *$ & 0.000 \\
\hline $\begin{array}{l}\text { Fraction of GSE mortgages } \\
\text { for non-owner-occupied home } \\
\text { in } 2005\end{array}$ & -0.015 & $-0.396^{* * *}$ & 0.000 \\
\hline Population change in $2003-06$ & -0.001 & 0.011 & 0.592 \\
\hline Ln of population in 2000 & -0.028 & $0.315^{* * *}$ & 0.000 \\
\hline $\begin{array}{l}\text { Fraction of the college } \\
\text { educated in } 2000\end{array}$ & $-0.175^{* * *}$ & $-0.553 * * *$ & 0.000 \\
\hline $\begin{array}{l}\text { Fraction of the employed in } \\
2000\end{array}$ & $-0.453 * * *$ & $-0.323 * * *$ & 0.000 \\
\hline Fraction of workforce in 2000 & $-0.446 * * *$ & $-0.224 * * *$ & 0.000 \\
\hline $\begin{array}{l}\text { Median household Income in } \\
2000\end{array}$ & $-0.423 * * *$ & $-0.404 * * *$ & 0.428 \\
\hline Poverty rate in 2000 & $0.393 * * *$ & $0.497 * * *$ & 0.000 \\
\hline Urban rate in 2000 & $0.078 * * *$ & $0.182 * * *$ & 0.000 \\
\hline Fraction of the white in 2000 & $-0.113 * * *$ & $-0.636 * * *$ & 0.000 \\
\hline $\begin{array}{l}\text { Dummy for states with non- } \\
\text { recourse mortgage law }\end{array}$ & $-0.084 * * *$ & $0.201 * * *$ & 0.000 \\
\hline Dummy for sand states & $0.318 * * *$ & $0.308 * * *$ & 0.648 \\
\hline Saiz's elasticity & $0.034 *$ & $-0.208 * * *$ & 0.000 \\
\hline Fraction of renters in 2000 & $0.236 * * *$ & $0.302 * * *$ & 0.000 \\
\hline $\begin{array}{l}\text { Fraction of immigrants in past } \\
5 \text { years }(2000)\end{array}$ & $0.219 * * *$ & $-0.157 * * *$ & 0.000 \\
\hline $\begin{array}{l}\text { Fraction of employment in } \\
\text { arts entertainment and } \\
\text { recreation in } 2000\end{array}$ & $0.580 * * *$ & $0.069 * * *$ & 0.000 \\
\hline
\end{tabular}


Table 2: Zip Codes near Borders of States without Capital Gains Taxes

Panel A of this table presents discontinuity tests for the fraction of non-owner-occupied home purchases in 2004-06 (Column 1) and the fraction of subprime mortgages in 2005 (Column 2) in zip codes near borders of states with no capital gains taxes. Panel B shows discontinuity tests for other control variables in zip codes near borders of states with no capital gains taxes. Distance from borders are divided by 1,000 and is negative on the side of neighboring states with capital gains taxes. We control for distance and its squared and cubic terms in all regressions (their coefficients are omitted to save space). Distance from borders are divided by 1,000 and is negative on the side of neighboring states with capital gains taxes. Standard errors are clustered at the state-border level. $* * *, * *, *$ indicate coefficient estimates statistically distinct from 0 at the $1 \%, 5 \%$, and $10 \%$ levels, respectively.

\section{Panel A}

(1)

Fraction of Non-Owner-Occupied Home Purchases in 2004-06

Dummy for states with

capital gains tax

Distance

Distance squared

Distance cubed

State-border X 10-

mile strips FE

Observations

R-squared

$$
-0.0487 * *
$$

$-2.241 * *$

$-40.59 *$

$1035.5 * *$

(397.3)

Yes

1072

0.347
(2)

Fraction of subprime mortgages in 2005

0.00182

(0.0248)

0.763

$-37.77^{*}$

$-66.09$

(423.6)

Yes

1072

0.185 


\section{Panel B}

\begin{tabular}{lcc}
\hline & $\begin{array}{c}\text { Dummy for states } \\
\text { with capital gains tax }\end{array}$ & $\begin{array}{l}\text { Standard } \\
\text { errors }\end{array}$ \\
\cline { 2 - 3 } Mortgage denial rate in 2005 & 0.00267 & $(0.0111)$ \\
Fraction of GSE mortgages in 2005 & -0.0109 & $(0.0638)$ \\
Non-owner-occupied home mortgage denial rate in 2005 & -0.0173 & $(0.0306)$ \\
Fraction of GSE mortgages for non-owner-occupied home in & & \\
2005 & -0.0690 & $(0.0602)$ \\
Population change in 2003-06 & -0.0368 & $(0.0277)$ \\
Ln of population in 2000 & 0.114 & $(0.157)$ \\
Fraction of the college educated in 2000 & -3.478 & $(1.607)$ \\
Fraction of the employed in 2000 & -1.560 & $(1.441)$ \\
Fraction of workforce in 2000 & -2.025 & $(1972.3)$ \\
Median household Income in 2000 & -2689.7 & $(1.434)$ \\
Poverty rate in 2000 & 0.296 & $(9.154)$ \\
Urban rate in 2000 & -0.998 & $(4.773)$ \\
Fraction of the white in 2000 & 3.712 & $(0.0336)$ \\
Fraction of renters in 2000 & -.002964 & $(0.0209)$ \\
Fraction of immigrants in past 5 years (2000) & -.0273 & $(0.0180)$ \\
Fraction of employment in arts entertainment and recreation in & & \\
2000 & -.00983 & \\
\hline
\end{tabular}




\section{Table 3: Speculation and Housing Price Cycles}

This table reports the two stage least squares regressions of the real house price change in 2004-2006 and 2007-2009 on the fraction of non-owner-occupied home purchases in 2004-2006 instrumented with the state capital gains tax rate for the median income. Column 1 shows the coefficients of the first stage regression of the fraction of non-owner-occupied home purchases in 2004-2006 on the state capital gains tax rate for the median income. Columns 2 and 3 show the coefficients of the second stage regression of the real house price changes in 2004-2006 and 2007-2009 respectively on the instrumented fraction of nonowner-occupied home purchases in 2004-2006. The regressions control for the supply elasticity measure, the fraction of subprime mortgages in 2005, the mortgage denial rate in 2005, the fraction of GSE mortgages in 2005, the mortgage denial rate for non-owner-occupied mortgages in 2005, the fraction of GSE mortgages for non-owner-occupied mortgages in 2005, per capita income change in 2003-2006, population change in 2003-2006, the change in the number of establishments in 2004-2006, real payroll change in 2004-2006, employment change in 2004-2006, the natural logarithm of population in 2000, the fraction of the college educated in 2000, the fraction of the employed in 2000, the fraction of workforce in 2000 , median household Income in 2000 , poverty rate in 2000 , urban rate in 2000 , the fraction of the white in 2000, the fraction of employment in arts, entertainment, and recreation in 2000, the fraction of renters in 2000 , the fraction of immigrants in 2000, the dummy for states with non-recourse mortgage law, and the dummy of sand states. Observations are weighted by the number of households. Standard errors are clustered at the state level. ***, **,* indicate coefficient estimates statistically distinct from 0 at the $1 \%$, $5 \%$, and $10 \%$ levels, respectively.

(1)

Fraction of non-owneroccupied home purchases in 2004-06

$-0.677 * *$

$(0.269)$

Fraction of non-owner-occupied home purchases in 2004-06

(2) Real house price change in 200406
(3)

Real house price change in 2007-

State capital gains tax rate for median income

(0.269) Saiz's elasticity
Fraction of subprime mortgages
in 2005

$0.0170 * * *$

$(0.00472)$

$-0.216 * * *$
$(0.0402)$

Mortgage denial rate in 2005

$0.509 * * *$

$(0.0819)$

$2.685^{* * *}$

(1.078)

$-3.785^{* * * *}$

$-0.114 * * *$

$(0.892)$

(0.0228)

$0.106 * * *$

(0.0231)

Fraction of GSE mortgages in 2005

$0.901 * * *$

$-1.691 * * *$

(0.286)

(0.256)

$-1.938 * * *$

1.086

(0.642)

$(0.780)$

Non-owner-occupied home mortgage denial rate in 2005

$-0.175^{* * *}$

(0.0362)

$0.620 * *$

$-0.682 * * *$

$(0.301)$

$(0.260)$

$-0.133^{* * *}$

(0.0323)
0.225

$(0.213)$
$-0.623 * * *$

(0.208) 
Fraction of GSE mortgages for non-owner-occupied home in 2005

0.0177
$(0.0198)$

$0.0954 * *$
$(0.0375)$
$-0.0417 * *$
$(0.0193)$

$0.0481 *$
$(0.0243)$
$0.0204 * * *$
$(0.00560)$
-0.00610
$(0.0106)$
$-0.0161 * * *$
$(0.00535)$

Per capita income change in 2003-06

Population change in 2003-06

Change in no. of establishments in 2004-06

Real payroll change in 2004-06

$0.00119 * * *$ in 2000

(0.000241)

Fraction of the employed in 2000

$-0.000672$

(0.00196)

Fraction of workforce in 2000

$-0.00140$

(0.00227)

Median household Income in 2000

$$
\begin{gathered}
-0.00000234 * * * \\
(0.000000261) \\
0.00233 * * \\
(0.000919) \\
0.000827 * * * \\
(0.000205)
\end{gathered}
$$

Poverty rate in 2000

Urban rate in 2000

Fraction of the white in 2000

$-0.000266$

$(0.000249)$

Fraction of renters in 2000

$-0.156^{* * * *}$

(0.0253)

Fraction of immigrants in 2000

$0.191 * * *$

(0.0346)

$-0.0616$

0.107

(0.0765)

(0.164)

0.0599

$0.395 *$

(0.185)

$(0.239)$

0.134

$-0.349 * * *$

(0.0894)

(0.112)

$0.223 *$

0.254

$(0.124)$

$(0.204)$

0.0113

$0.0959 *$

(0.0296)

(0.0490)

$-0.0101$

$-0.0813^{*}$

(0.0300)

(0.0490)

0.0352

$-0.0706 * *$

(0.0288)

(0.0348)

$-0.00488 * * *$

$0.00339 *$

(0.00146)

(0.00197)

$-0.00875$

$-0.00339$

(0.00869)

(0.0171)

0.0114

$-0.00239$

(0.00968)

(0.0171)

$0.00000587 * * \quad-0.00000811 * * *$

$(0.00000285) \quad(0.00000289)$

$-0.00657 * \quad 0.00632$

(0.00397)

(0.00449)

$-0.00204 *$

$0.00249 * *$

$(0.00120)$

(0.00113)

0.0000601

$-0.00307 * * *$

(0.000989)

(0.000936)

$0.511^{* *}$

$-0.268$

$(0.202)$

$(0.265)$

$-0.412$

0.401

(0.289)

(0.387)

Fraction of employment in arts entertainment and recreation in 2000

$0.742 * * *$

$-1.983 * *$

$2.339 * * *$

(0.117)

(0.840)

(0.798)

Dummy for states with nonrecourse mortgage law

0.0123
$(0.0176)$

$-0.0155$

0.0976*

(0.0409)

(0.0523) 


\begin{tabular}{lccc} 
Dummy for sand states & -0.0227 & $0.229 * * *$ & $-0.383 * * *$ \\
Constant & $(0.0190)$ & $(0.0525)$ & $(0.0658)$ \\
& $0.408 * * *$ & -0.458 & $1.532 * * *$ \\
Observations & $(0.111)$ & $(0.650)$ & $(0.517)$ \\
First-stage F statistic & 3935 & 3935 & 3935 \\
R-squared & 69.93 & $\mathrm{NA}$ & $\mathrm{NA}$ \\
\hline
\end{tabular}




\section{Table 4: Extrapolation and Housing Speculation}

This table reports coefficient estimates from regressing the fraction of non-owner-occupied home purchases in 2004-2006 on the house price change in 2001-2003 (Columns 1), the state capital gains tax rate for the median income, and their interaction (Columns 2). All regressions control for the host of lagged variables including the fraction of subprime mortgages in 2002, mortgage denial rate in 2002, the fraction of GSE mortgages in 2002, the mortgage denial rate for non-owner-occupied mortgages in 2002, the fraction of GSE mortgages for non-owner-occupied mortgages in 2002, per capita income change in 2001-2002, the population change in 2001-2002, the change in the number of establishments in 2001-2003, the real payroll change in 2001-2003, the employment change in 2001-2003, the natural logarithm of population in 2000, the fraction of the college educated in 2000 , the fraction of the employed in 2000 , the fraction of workforce in 2000, median household Income in 2000, poverty rate in 2000, urban rate in 2000, the fraction of the white in 2000, the fraction of employment in arts, entertainment, and recreation in 2000, the fraction of renters in 2000, the fraction of immigrants in 2000, as well as the dummy for states with non-recourse mortgage law and the dummy of sand states. Observations are weighted by the number of households. Standard errors are clustered at the state level. ***, **,* indicate coefficient estimates statistically distinct from 0 at the $1 \%, 5 \%$, and $10 \%$ levels, respectively. Observations are weighted by the number of households. Standard errors are clustered at the state level. $* * *, * *, *$ indicate coefficient estimates statistically distinct from 0 at the $1 \%, 5 \%$, and $10 \%$ levels, respectively.

(1)

Fraction of Non-Owner-Occupied Home Purchases in 2004-06

Real house

0.0231

$0.229 * * *$

price change in 2001-03

Interaction

State capital

gain tax rate for median income

Constant

$0.283 * * *$

$0.260 * * *$

Controls

(0.0768)

(0.0818)

Observations

Yes

Yes

R-squared

3379

3379

0.552

0.593 


\section{Table 5: Real Effects of Housing Speculation}

This table reports the two stage least squares regressions of economic outcomes in 2004-2006 (Panel A: The boom period) and in 2007-2009 (Panel B: The bust period) on the fraction of non-owner-occupied home purchases in 2004-2006 instrumented with the state capital gains tax rate for the median income. All regressions control for the supply elasticity measure, the fraction of subprime mortgages in 2005, the mortgage denial rate in 2005, the fraction of GSE mortgages in 2005, the mortgage denial rate for nonowner-occupied mortgages in 2005, the fraction of GSE mortgages for non-owner-occupied mortgages in 2005, population change in 2003-2006, per capita income change in 2003-2006, the change in the number of establishments in 2004-2006, real payroll change in 2004-2006, employment change in 2004-2006, the natural logarithm of population in 2000, the fraction of the college educated in 2000, the fraction of the employed in 2000, the fraction of workforce in 2000, median household Income in 2000, poverty rate in 2000 , urban rate in 2000, the fraction of the white in 2000, the fraction of employment in arts, entertainment, and recreation in 2000, the fraction of renters in 2000, the fraction of immigrants in 2000, the dummy for states with non-recourse mortgage law, and the dummy of sand states. Observations are weighted by the number of households. Standard errors are clustered at the state level. ***, **, * indicate coefficient estimates statistically distinct from 0 at the $1 \%, 5 \%$, and $10 \%$ levels, respectively.

Panel A: The boom period

\begin{tabular}{|c|c|c|c|c|}
\hline & $\begin{array}{c}\text { (1) } \\
\text { Per capita } \\
\text { income change } \\
\text { in 2003-06 }\end{array}$ & $\begin{array}{c}\text { (2) } \\
\text { Change in no. } \\
\text { of } \\
\text { establishments } \\
\text { in 2004-06 } \\
\end{array}$ & $\begin{array}{c}\text { (3) } \\
\text { Real payroll } \\
\text { change in 2004- } \\
06 \\
\end{array}$ & $\begin{array}{c}(4) \\
\text { Employment } \\
\text { change in } \\
2004-06\end{array}$ \\
\hline $\begin{array}{l}\text { Fraction of non-owner- } \\
\text { occupied home purchases in } \\
2004-06\end{array}$ & $\begin{array}{l}1.305 * * * \\
(0.347)\end{array}$ & $\begin{array}{l}0.687 * * * \\
(0.245)\end{array}$ & $\begin{array}{l}1.383 * * * \\
(0.431)\end{array}$ & $\begin{array}{l}0.850 * * * \\
(0.301)\end{array}$ \\
\hline Saiz's elasticity & $\begin{array}{c}-0.0410 * * * \\
(0.00887)\end{array}$ & $\begin{array}{c}-0.0301 * * * \\
(0.00605)\end{array}$ & $\begin{array}{l}-0.0290 * * * \\
(0.00502)\end{array}$ & $\begin{array}{c}-0.0218 * * * \\
(0.00408)\end{array}$ \\
\hline $\begin{array}{l}\text { Fraction of subprime } \\
\text { mortgages in } 2005\end{array}$ & $\begin{array}{c}0.0962 \\
(0.0961)\end{array}$ & $\begin{array}{c}0.128 \\
(0.0887)\end{array}$ & $\begin{array}{l}0.296 * \\
(0.152)\end{array}$ & $\begin{array}{l}0.182 * \\
(0.101)\end{array}$ \\
\hline Mortgage denial rate in 2005 & $\begin{array}{c}-0.747 * * * \\
(0.211)\end{array}$ & $\begin{array}{c}-0.390 * * \\
(0.156)\end{array}$ & $\begin{array}{c}-0.869 * * * \\
(0.296)\end{array}$ & $\begin{array}{l}-0.552 * * \\
(0.224)\end{array}$ \\
\hline $\begin{array}{l}\text { Fraction of GSE mortgages in } \\
2005\end{array}$ & $\begin{array}{c}0.0665 \\
(0.0746)\end{array}$ & $\begin{array}{l}0.196 * * \\
(0.0831)\end{array}$ & $\begin{array}{c}0.324 * * * \\
(0.106)\end{array}$ & $\begin{array}{l}0.247 * * * \\
(0.0888)\end{array}$ \\
\hline $\begin{array}{l}\text { Non-owner-occupied home } \\
\text { mortgage denial rate in } 2005\end{array}$ & $\begin{array}{l}0.160 * * \\
(0.0756)\end{array}$ & $\begin{array}{c}0.0629 \\
(0.0402)\end{array}$ & $\begin{array}{c}0.153^{*} \\
(0.0805)\end{array}$ & $\begin{array}{c}0.0556 \\
(0.0485)\end{array}$ \\
\hline $\begin{array}{l}\text { Fraction of GSE mortgages } \\
\text { for non-owner-occupied } \\
\text { home in } 2005\end{array}$ & $\begin{array}{l}-0.0686 * \\
(0.0384)\end{array}$ & $\begin{array}{c}0.0410 \\
(0.0256)\end{array}$ & $\begin{array}{l}-0.00600 \\
(0.0483)\end{array}$ & $\begin{array}{c}0.0341 \\
(0.0418)\end{array}$ \\
\hline Population change in $2003-06$ & -0.0635 & $0.324 * * *$ & $0.300 * * *$ & $0.300 * * *$ \\
\hline
\end{tabular}




\begin{tabular}{|c|c|c|c|c|}
\hline & $(0.0688)$ & $(0.0460)$ & $(0.0540)$ & $(0.0623)$ \\
\hline \multirow[t]{2}{*}{ Ln of population in 2000} & 0.00197 & $0.0186 * * *$ & $0.0273 * * *$ & $0.0193 * * *$ \\
\hline & $(0.0103)$ & $(0.00629)$ & $(0.00909)$ & $(0.00571)$ \\
\hline \multirow{2}{*}{$\begin{array}{l}\text { Fraction of the college } \\
\text { educated in } 2000\end{array}$} & & & & \\
\hline & $0.00167 * *$ & -0.000693 & $-0.00243 * * *$ & $-0.00208 * * *$ \\
\hline \multirow{3}{*}{$\begin{array}{l}\text { Fraction of the employed in } \\
2000\end{array}$} & (0.000693) & $(0.000507)$ & $(0.000912)$ & \\
\hline & -0.00263 & 0.000487 & 0.00130 & 0.000343 \\
\hline & $(0.00324)$ & $(0.00201)$ & $(0.00383)$ & $(0.00333)$ \\
\hline \multirow[t]{2}{*}{ Fraction of workforce in 2000} & 0.00210 & 0.00184 & 0.00306 & 0.00318 \\
\hline & $(0.00374)$ & $(0.00233)$ & $(0.00413)$ & $(0.00362)$ \\
\hline \multirow{3}{*}{$\begin{array}{l}\text { Median household Income in } \\
2000\end{array}$} & & & & \\
\hline & $0.00000304 * * *$ & 0.00000104 & $0.00000394 * * *$ & $0.00000265 * * *$ \\
\hline & $(0.000000819)$ & $(0.000000665)$ & $(0.00000129)$ & $(0.000000996)$ \\
\hline \multirow[t]{2}{*}{ Poverty rate in 2000} & -0.00121 & $-0.00243 * * *$ & -0.00137 & -0.00108 \\
\hline & $(0.00152)$ & $(0.000771)$ & $(0.00189)$ & $(0.00119)$ \\
\hline \multirow[t]{2}{*}{ Urban rate in 2000} & $-0.00191 * * *$ & $-0.000832 * *$ & $-0.00129 * * *$ & $-0.000929 * * *$ \\
\hline & $(0.000306)$ & $(0.000346)$ & $(0.000422)$ & $(0.000322)$ \\
\hline \multirow[t]{2}{*}{ Fraction of the white in 2000} & $0.00109 * * *$ & -0.0000902 & 0.000475 & 0.000386 \\
\hline & $(0.000375)$ & $(0.000209)$ & $(0.000314)$ & $(0.000275)$ \\
\hline \multirow{3}{*}{$\begin{array}{l}\text { Fraction of employment in } \\
\text { arts entertainment and } \\
\text { recreation in } 2000\end{array}$} & & & & \\
\hline & $-0.792 * *$ & $-0.397 *$ & $-0.868 * *$ & $-0.438 *$ \\
\hline & $(0.402)$ & $(0.217)$ & $(0.365)$ & $(0.262)$ \\
\hline \multirow[t]{2}{*}{ Fraction of renters in 2000} & $0.181 * * *$ & -0.0167 & 0.112 & 0.0291 \\
\hline & $(0.0684)$ & $(0.0457)$ & $(0.102)$ & $(0.0700)$ \\
\hline \multirow{3}{*}{$\begin{array}{l}\text { Fraction of immigrants in } \\
2000\end{array}$} & & & & \\
\hline & $-0.284 * * *$ & 0.0968 & 0.0958 & $0.108 *$ \\
\hline & $(0.0996)$ & $(0.0747)$ & $(0.0819)$ & $(0.0641)$ \\
\hline \multirow[t]{2}{*}{$\begin{array}{l}\text { Dummy for states with non- } \\
\text { recourse mortgage law }\end{array}$} & -0.00485 & -0.00965 & 0.00965 & 0.00197 \\
\hline & $(0.0165)$ & $(0.0108)$ & $(0.0207)$ & $(0.0134)$ \\
\hline \multirow[t]{2}{*}{ Dummy for sand states } & $0.0481 * *$ & $0.0511 * * *$ & $0.0883 * * *$ & $0.0684 * * *$ \\
\hline & $(0.0234)$ & $(0.0149)$ & $(0.0233)$ & $(0.0175)$ \\
\hline \multirow[t]{2}{*}{ Constant } & -0.0314 & $-0.284 *$ & $-0.704 * * *$ & $-0.497 * * *$ \\
\hline & $(0.238)$ & $(0.166)$ & $(0.242)$ & $(0.154)$ \\
\hline Observations & 3935 & 3935 & 3935 & 3935 \\
\hline R-squared & 0.211 & 0.251 & 0.102 & 0.082 \\
\hline
\end{tabular}




\begin{tabular}{|c|c|c|c|c|}
\hline & $\begin{array}{l}(1) \\
\text { Per capita income } \\
\text { change in 2007- } \\
09\end{array}$ & $\begin{array}{l}\text { Change in no. of } \\
\text { establishments } \\
\text { in 2007-09 }\end{array}$ & $\begin{array}{c}(3) \\
\text { Real payroll } \\
\text { change in 2007- } \\
09\end{array}$ & $\begin{array}{c}(4) \\
\text { Employment } \\
\text { change in 2007- } \\
09\end{array}$ \\
\hline $\begin{array}{l}\text { Fraction of non-owner- } \\
\text { occupied home purchases in } \\
2004-06\end{array}$ & $\begin{array}{c}-0.794 * * * \\
(0.199)\end{array}$ & $\begin{array}{c}-0.877 * * * \\
(0.205)\end{array}$ & $\begin{array}{c}-1.563 * * * \\
(0.356)\end{array}$ & $\begin{array}{c}-1.475 * * * \\
(0.341)\end{array}$ \\
\hline Saiz's elasticity & $\begin{array}{l}-0.00524 \\
(0.00614)\end{array}$ & $\begin{array}{l}0.00724 * \\
(0.00393)\end{array}$ & $\begin{array}{l}0.0281 * * * \\
(0.00596)\end{array}$ & $\begin{array}{l}0.0246 * * * \\
(0.00611)\end{array}$ \\
\hline $\begin{array}{l}\text { Fraction of subprime } \\
\text { mortgages in } 2005\end{array}$ & $\begin{array}{c}-0.284 * * * \\
(0.0544)\end{array}$ & $\begin{array}{c}-0.232 * * * \\
(0.0489)\end{array}$ & $\begin{array}{c}-0.378 * * * \\
(0.108)\end{array}$ & $\begin{array}{c}-0.369 * * * \\
(0.0910)\end{array}$ \\
\hline Mortgage denial rate in 2005 & $\begin{array}{l}0.0191 \\
(0.164)\end{array}$ & $\begin{array}{c}0.325 * * * \\
(0.115)\end{array}$ & $\begin{array}{c}0.730 * * * \\
(0.225)\end{array}$ & $\begin{array}{c}0.688 * * * \\
(0.195)\end{array}$ \\
\hline $\begin{array}{l}\text { Fraction of GSE mortgages in } \\
2005\end{array}$ & $\begin{array}{c}-0.141 * * * \\
(0.0480)\end{array}$ & $\begin{array}{l}-0.112 * * \\
(0.0503)\end{array}$ & $\begin{array}{c}-0.265^{* * *} \\
(0.0997)\end{array}$ & $\begin{array}{c}-0.230 * * * \\
(0.0891)\end{array}$ \\
\hline $\begin{array}{l}\text { Non-owner-occupied home } \\
\text { mortgage denial rate in } 2005\end{array}$ & $\begin{array}{c}-0.0828 * * \\
(0.0378)\end{array}$ & $\begin{array}{c}-0.147 * * * \\
(0.0410)\end{array}$ & $\begin{array}{c}-0.277 * * * \\
(0.0893)\end{array}$ & $\begin{array}{l}-0.202 * * \\
(0.0792)\end{array}$ \\
\hline $\begin{array}{l}\text { Fraction of GSE mortgages } \\
\text { for non-owner-occupied } \\
\text { home in } 2005\end{array}$ & $\begin{array}{c}0.0387 \\
(0.0416)\end{array}$ & $\begin{array}{c}0.0205 \\
(0.0152)\end{array}$ & $\begin{array}{c}0.0363 \\
(0.0437)\end{array}$ & $\begin{array}{c}0.0123 \\
(0.0314)\end{array}$ \\
\hline $\begin{array}{l}\text { Per capita income change in } \\
2003-06\end{array}$ & $\begin{array}{l}-0.184 * * \\
(0.0836)\end{array}$ & $\begin{array}{l}0.134 * * * \\
(0.0370)\end{array}$ & $\begin{array}{l}0.261 * * * \\
(0.0692)\end{array}$ & $\begin{array}{l}0.195 * * * \\
(0.0740)\end{array}$ \\
\hline Population change in 2003-06 & $\begin{array}{c}-0.159 * * * \\
(0.0514)\end{array}$ & $\begin{array}{l}0.164 * * * \\
(0.0238)\end{array}$ & $\begin{array}{l}0.119 * * \\
(0.0505)\end{array}$ & $\begin{array}{l}0.115 * * \\
(0.0476)\end{array}$ \\
\hline $\begin{array}{l}\text { Change in no. of } \\
\text { establishments in 2004-06 }\end{array}$ & $\begin{array}{l}0.182 * * * \\
(0.0450)\end{array}$ & $\begin{array}{l}0.191 * * * \\
(0.0516)\end{array}$ & $\begin{array}{c}0.479 * * * \\
(0.0996)\end{array}$ & $\begin{array}{l}0.523 * * * \\
(0.0964)\end{array}$ \\
\hline $\begin{array}{l}\text { Real payroll change in } 2004- \\
06\end{array}$ & $\begin{array}{c}0.0300 \\
(0.0194)\end{array}$ & $\begin{array}{c}0.0326 * * \\
(0.0126)\end{array}$ & $\begin{array}{l}-0.107 * * \\
(0.0503)\end{array}$ & $\begin{array}{c}0.162 * * * \\
(0.0327)\end{array}$ \\
\hline $\begin{array}{l}\text { Employment change in 2004- } \\
06\end{array}$ & $\begin{array}{l}-0.0113 \\
(0.0157)\end{array}$ & $\begin{array}{l}-0.0134 \\
(0.0126)\end{array}$ & $\begin{array}{l}-0.0133 \\
(0.0357)\end{array}$ & $\begin{array}{c}-0.308 * * * \\
(0.0290)\end{array}$ \\
\hline Ln of population in 2000 & $\begin{array}{c}-0.0217 * * * \\
(0.00579)\end{array}$ & $\begin{array}{c}-0.0144 * * * \\
(0.00537)\end{array}$ & $\begin{array}{c}-0.0249 * * \\
(0.0109)\end{array}$ & $\begin{array}{c}-0.0279 * * * \\
(0.00872)\end{array}$ \\
\hline $\begin{array}{l}\text { Fraction of the college } \\
\text { educated in } 2000\end{array}$ & $\begin{array}{l}-0.000532 \\
(0.000473)\end{array}$ & $\begin{array}{l}0.00115 * * * \\
(0.000349)\end{array}$ & $\begin{array}{r}0.00379 * * * \\
(0.000561)\end{array}$ & $\begin{array}{r}0.00277 * * * \\
(0.000407)\end{array}$ \\
\hline
\end{tabular}


Fraction of the employed in 2000

$\begin{array}{cccc}-0.00271 & -0.00450 * * & -0.0110 * * * & -0.00777 * * * \\ (0.00275) & (0.00223) & (0.00395) & (0.00281) \\ 0.00259 & 0.00295 & 0.00809^{* *} & 0.00526 \\ (0.00277) & (0.00239) & (0.00401) & (0.00324) \\ & & & \\ -0.00000261 * * * & -0.00000178^{* * *} & -0.00000479 * * * & -0.00000376^{* * *} \\ (0.000000690) & (0.000000616) & (0.00000111) & (0.000000854) \\ 0.00161 & 0.00182 & 0.00331 & 0.00325^{*} \\ (0.00115) & (0.00122) & (0.00204) & (0.00190) \\ 0.0000585 & 0.000813 * * * & 0.00190^{* * *} & 0.00151^{* * *} \\ (0.000221) & (0.000210) & (0.000413) & (0.000408) \\ -0.00143 * * * & -0.000621 * * * & -0.000887 * & -0.000764 * * \\ (0.000278) & (0.000191) & (0.000460) & (0.000342)\end{array}$

Fraction of employment in arts entertainment and recreation in 2000

$$
\begin{aligned}
& 0.252 * \\
& (0.152)
\end{aligned}
$$$$
0.642 * * *
$$$$
1.115 * * *
$$$$
1.091 * * *
$$

Fraction of renters in 2000

$$
-0.120 * *
$$

(0.165)

(0.0570)

$-0.113^{* *}$

(0.297)

(0.333)

Fraction of immigrants in 2000

$$
\begin{gathered}
-0.0908^{*} \\
(0.0545)
\end{gathered}
$$$$
\text { (0.0482) }
$$

$-0.277 * * *$

$-0.239 * * *$

0.0276

(0.0587)

(0.0950)

(0.0739)

Dummy for states with nonrecourse mortgage law

$-0.000547$

$0.0126^{*}$

0.0368

0.0523

(0.107)

(0.0905)

(0.0115)

(0.00749)

$-0.0332 *$

$-0.0324 * * *$

$0.0349 * *$

$0.0366^{* * * *}$

Dummy for sand states

(0.0175)

(0.0119)

$0.591 * * *$

$0.305^{* * *}$

(0.0921)

(0.116)

(0.0144)

(0.0141)

$-0.0883 * * *$

$-0.0877 * * *$

Constant

3934

3904

(0.0231)

(0.0249)

$0.489 * * *$

$0.493^{* * *}$

(0.181)

(0.175)

Observations

0.237

0.241 


\section{Table 6: Speculation and New Housing Supply}

This table reports the two stage least squares regressions of building permits in 2004-06 relative to the housing units in 2000 on the fraction of non-owner-occupied home purchases in 2004-2006 instrumented with the state capital gains tax rate for the median income. Column 1 shows the coefficients of the first stage regression of the fraction of non-owner-occupied home purchases in 2004-2006 on the state capital gains tax rate for the median income. Column 2 shows the coefficients of the second stage regression of building permits in 2004-2006 relative to the housing units in 2000 on the instrumented fraction of nonowner-occupied home purchases in 2004-2006. All regressions control for the supply elasticity measure, the fraction of subprime mortgages in 2005, the mortgage denial rate in 2005, the fraction of GSE mortgages in 2005, the mortgage denial rate for non-owner-occupied mortgages in 2005, the fraction of GSE mortgages for non-owner-occupied mortgages in 2005, per capita income change in 2003-2006, population change in 2003-2006, the change in the number of establishments in 2004-2006, real payroll change in 2004-2006, employment change in 2004-2006, the natural logarithm of population in 2000, the fraction of the college educated in 2000, the fraction of the employed in 2000, the fraction of workforce in 2000, median household Income in 2000, poverty rate in 2000, urban rate in 2000, the fraction of the white in 2000 , , the fraction of employment in arts, entertainment, and recreation in 2000, the fraction of renters in 2000 , the fraction of immigrants in 2000, the dummy for states with non-recourse mortgage law, and the dummy of sand states. Observations are weighted by the number of households at the county level. Standard errors are clustered at the state level. $* * *, * *, *$ indicate coefficient estimates statistically distinct from 0 at the $1 \%, 5 \%$, and $10 \%$ levels, respectively.

\begin{tabular}{lcc}
\hline & $\begin{array}{c}(1) \\
\text { Fraction of Non-Owner- } \\
\text { Occupied Home Purchases } \\
\text { in 2004-06 }\end{array}$ & $\begin{array}{c}(2) \\
\text { Building permits in 2004-06 } \\
\text { relative to the housing units in } \\
\text { State capital gains tax rate for }\end{array}$ \\
\cline { 2 - 3 } median income & $-0.822^{* * *}$ & 2000 \\
Fraction of Non-Owner-Occupied & $(0.138)$ & \\
Home Purchases in 2004-06 & & $0.428^{* * *}$ \\
Constant & & $(0.105)$ \\
& $0.656^{* * *}$ & $-0.263^{* *}$ \\
Controls & $(0.104)$ & $(0.114)$ \\
Observations & Yes & Yes \\
First stage F statistics & 309 & 309 \\
R-squared & 19.75 & NA \\
\hline
\end{tabular}




\section{Table 7: Effects of Housing Speculation on Construction and Non-construction Sectors}

This table reports the two stage least squares regressions of the employment change in the construction (Column 1) and non-construction sectors (Column 2) in 2004-2006 (Panel A: The boom period) and in 2007-2009 (Panel B: The bust period) on the fraction of non-owner-occupied home purchases in 2004-2006 instrumented with the state capital gains tax rate for the median income. All regressions control for the supply elasticity measure, the fraction of subprime mortgages in 2005, the mortgage denial rate in 2005, the fraction of GSE mortgages in 2005, the mortgage denial rate for non-owner-occupied mortgages in 2005, the fraction of GSE mortgages for non-owner-occupied mortgages in 2005, population change in 2003-2006, per capita income change in 2003-2006, the change in the number of establishments in 20042006, real payroll change in 2004-2006, employment change in 2004-2006, the natural logarithm of population in 2000 , the fraction of the college educated in 2000 , the fraction of the employed in 2000 , the fraction of workforce in 2000, median household Income in 2000, poverty rate in 2000, urban rate in 2000, the fraction of the white in 2000, the fraction of employment in arts, entertainment, and recreation in 2000, the fraction of renters in 2000, the fraction of immigrants in 2000, the dummy for states with non-recourse mortgage law, and the dummy of sand states. Observations are weighted by the number of households. Standard errors are clustered at the state level. $* * *, * *, *$ indicate coefficient estimates statistically distinct from 0 at the $1 \%, 5 \%$, and $10 \%$ levels, respectively.

\section{Panel A: The boom period}

(1)

Construction employment change in 2004-06
(2)

Non-construction employment change in 2004-06

\begin{tabular}{lcc} 
Fraction of Non-Owner-Occupied & $2.543 * * *$ & $0.624 * * *$ \\
Home Purchases in 2004-06 & $(0.811)$ & $(0.239)$ \\
Constant & -0.676 & $-0.477 * * *$ \\
& $(0.513)$ & $(0.123)$ \\
Controls & Yes & Yes \\
Observations & 3966 & 3933 \\
R-squared & 0.104 & 0.088 \\
\hline
\end{tabular}


Panel B: The bust period

(1)

Construction employment Non-construction employment change in 2007-09

Fraction of Non-Owner-Occupied

Home Purchases in 2004-06

Constant

Controls

Observations

R-squared
$-3.422 * * *$

(0.720)

$1.034 * * *$

$(0.345)$

Yes

3933

0.089
(2) change in 2007-09

$$
\begin{gathered}
-1.253 * * * \\
(0.330) \\
0.459 * * * \\
(0.167)
\end{gathered}
$$

Yes

3902

0.065 


\section{Table 8: Effect of Housing Speculation: Demand Channel}

This table reports the two stage least squares regressions of the employment change in non-tradable and tradable sectors in 2004-2006 (Panel A: The boom period) and in 2007-2009 (Panel B: The bust period) on the fraction of non-owner-occupied home purchases in 2004-2006 instrumented with the state capital gains tax rate for the median income. Columns 1 and 2 present the coefficients for non-tradable and tradable industries respectively defined by Mian and Sufi (2014). Columns 3 and 4 present the results for retail and restaurant sectors and industries other than these two sectors, respectively. All regressions control for the supply elasticity measure, the fraction of subprime mortgages in 2005, the mortgage denial rate in 2005, the fraction of GSE mortgages in 2005, the mortgage denial rate for non-owner-occupied mortgages in 2005, the fraction of GSE mortgages for non-owner-occupied mortgages in 2005, population change in 2003-2006, per capita income change in 2003-2006, the change in the number of establishments in 20042006, real payroll change in 2004-2006, employment change in 2004-2006, the natural logarithm of population in 2000 , the fraction of the college educated in 2000 , the fraction of the employed in 2000 , the fraction of workforce in 2000, median household Income in 2000, poverty rate in 2000, urban rate in 2000, the fraction of the white in 2000, the fraction of employment in arts, entertainment, and recreation in 2000, the fraction of renters in 2000, the fraction of immigrants in 2000, the dummy for states with non-recourse mortgage law, and the dummy of sand states. Observations are weighted by the number of households. Standard errors are clustered at the state level. $* * *, * *, *$ indicate coefficient estimates statistically distinct from 0 at the $1 \%, 5 \%$, and $10 \%$ levels, respectively.

\section{Panel A: The boom period}

\begin{tabular}{lcccc}
\hline & $\begin{array}{c}(1) \\
\text { Employment } \\
\text { change in non- } \\
\text { tradable } \\
\text { industries in } \\
2004-06\end{array}$ & $\begin{array}{c}(2) \\
\text { Employment } \\
\text { change in } \\
\text { tradable } \\
\text { industries in } \\
2004-06\end{array}$ & $\begin{array}{c}(3) \\
\text { Retail and } \\
\text { restaurant } \\
\text { employment } \\
\text { change in } \\
2004-06\end{array}$ & $\begin{array}{c}(4) \\
\text { Employment } \\
\text { change in industries } \\
\text { other than retail } \\
\text { and restaurant in } \\
2004-06\end{array}$ \\
\cline { 2 - 5 } $\begin{array}{l}\text { Fraction of Non- } \\
\text { Owner-Occupied Home }\end{array}$ & $0.889 * * *$ & 0.558 & $0.904 * * *$ & \\
Purchases in 2004-06 & $(0.265)$ & $(0.685)$ & $(0.261)$ & 0.448 \\
Constant & $-0.404 * *$ & -0.143 & $-0.469 * * *$ & $(0.274)$ \\
Controls & $(0.163)$ & $(0.327)$ & $(0.155)$ & $-0.483 * * *$ \\
Observations & Yes & Yes & Yes & $(0.142)$ \\
R-squared & 3969 & 3898 & 3969 & Yes \\
\hline
\end{tabular}


Panel B: The bust period

\begin{tabular}{|c|c|c|c|c|}
\hline & $\begin{array}{l}(1) \\
\text { Employment } \\
\text { change in non- } \\
\text { tradable } \\
\text { industries in } \\
2007-09 \\
\end{array}$ & $\begin{array}{l}(2) \\
\text { Employment } \\
\text { change in } \\
\text { tradable } \\
\text { industries in } \\
2007-09\end{array}$ & $\begin{array}{l}(3) \\
\text { Retail and } \\
\text { restaurant } \\
\text { employment } \\
\text { change in } \\
\text { 2007-09 }\end{array}$ & $\begin{array}{c}\text { (4) } \\
\text { Employment } \\
\text { change in industries } \\
\text { other than retail } \\
\text { and restaurant in } \\
2007-09\end{array}$ \\
\hline $\begin{array}{l}\text { Fraction of Non- } \\
\text { Owner-Occupied Home } \\
\text { Purchases in 2004-06 }\end{array}$ & $\begin{array}{c}-1.534 * * * \\
(0.408)\end{array}$ & $\begin{array}{l}-0.297 \\
(0.680)\end{array}$ & $\begin{array}{c}-1.585^{* * * *} \\
(0.590)\end{array}$ & $\begin{array}{c}-1.131 * * * \\
(0.417)\end{array}$ \\
\hline Constant & $\begin{array}{c}0.577 * * \\
(0.227)\end{array}$ & $\begin{array}{l}-0.467 \\
(0.376)\end{array}$ & $\begin{array}{l}0.569^{*} \\
(0.314)\end{array}$ & $\begin{array}{c}0.381 * * \\
(0.184)\end{array}$ \\
\hline Controls & Yes & Yes & Yes & Yes \\
\hline $\begin{array}{l}\text { Observations } \\
\text { R-squared }\end{array}$ & $\begin{array}{l}3934 \\
0.067\end{array}$ & $\begin{array}{l}3851 \\
0.005\end{array}$ & $\begin{array}{l}3935 \\
0.037\end{array}$ & $\begin{array}{l}3899 \\
0.010\end{array}$ \\
\hline
\end{tabular}

